No. 5

\title{
SEGTION 301 AND EXHAUSTION OF INTRA-UNION APPEALS: A MISBEGOTTEN MARRIAGE
}

\author{
Arthur L. Fox II $\dagger$ \\ and Robert B. Sonenthal
}

The Supreme Court has firmly established that workers covered by collective bargaining agxeements can enforce individual employee rights arising from such contracts by suing their employers under section 301 of the Labor Management Relations Act. ${ }^{1}$ At the same time, however, the employee who brings a section 301 action must comply with a series of court-imposed prerequisites before the merits of his contract claim will be heard. To encourage private settlement of contract disputes, the Supreme Court has decreed that an employee who wishes to sue under section 301 must first exhaust the grievance procedures provided in the collective bargaining agreement ${ }^{2}$ unless he can demonstrate that his union's refusal to pursue his grievance constitutes a breach of its duty of fair representation. ${ }^{3}$ More recently, the lower federal courts have imposed yet another, peculiarly ill-suited prerequisite: exhaustion of intra-union appeals.

f A.B. 1965, LL.B. 1968, University of Virginia. Member, District of Columbia and Virginia Bars. Mr. Fox is currently associated with the Public Citizen Litigation Group in Washington, D.C., where he specializes in the representation of rank-and-file workers.

if A.B. 1970, Harvard University; M.A. 1972, Columbia University; J.D. 1980, University of Pennsylvania.

1 Smith v. Evening News Ass'n, 371 U.S. 195, 198-200 (1962). Section 301(a) provides:

Suits for violation of contracts between an employer and a labor organization representing employees in an industry affecting commerce as defined in this chapter, or between any such labor organizations, may be brought in any district court of the United States having jurisdiction of the parties, without respect to the amount in controversy or without regard to the citizenship of the parties.

Labor Management Relations Act $\$ 301$ (a), 29 U.S.C. \$185(a) (1976).

Although the specific subsection which is the subject of this Article is $\$ 301$ (a), we will, for simplicity's sake, follow the common practice of referring to it as $\$ 301$. See Feller, A General Theory of the Collective Bargaining Agreement, 61 CAIIF. L. REv. 663, 686-87 n.122 (1973).

2 Republic Steel Corp. v. Maddox, 379 U.S. 650 (1965).

3 Vaca v. Sipes, 386 U.S. 171 (1967). 
Consider the case of Charles Aldridge, an experienced tool-anddie inspector for Ludwig-Honold Manufacturing Company.4 Following a layoff of questionable propriety, Aldridge was rehired at a grade and salary level lower than the one he was entitled to under the collective bargaining agreement. Just before recommencing work, he lodged a formal complaint with the union official responsible for filing and processing grievances; however, no grievance was filed. When Aldridge subsequently discovered the union's omission, he filed his own grievance though the five-day contract statute of limitations on filing grievances had run. The company rejected this grievance as untimely, and the union declined to process it to arbitration because it was likely to be rejected on grounds of timeliness. Aldridge then sued Ludwig-Honold in a federal district court for breach of contract and joined his union as party-defendant, alleging that the latter breached its duty of fair representation when handling his grievance. Although the court was troubled by the apparent contract violation and questioned the union's judgment in refusing to process fully Aldridge's grievance, it granted the defendants' motion for summary judgment because Aldridge had failed to appeal "his union representative's decision not to assert his grievance within the union itself." 5 In theory, the court had done no more than to withhold its jurisdiction temporarily; in fact, this form of judicial abstention will often frustrate pursuit of contract claims and effectively insulate both employer and union from liability.

Charles Aldridge's predicament is by no means unusual. In recent years, the notion that a section 301 plaintiff must, before filing suit, exhaust not only his contract grievance procedures but also all internal union appeals, has matured into legal dogma. Indeed, it is now rare that a section 301 plaintiff does not encounter this defense at the threshold of his action. ${ }^{6}$ In the Aldridge case, for example, the district court confidently assumed that the intraunion exhaustion principle was beyond question. Without analyzing the consequences or purposes of requiring intra-union exhaustion in the case before it, the court simply noted that because the union constitution contained an appeals procedure for challenging union decisions, Aldridge was obligated to exhaust that procedure before initiating a section 301 suit. $^{7}$ The court was satisfied to repeat the formulas of prior decisions.

4 Aldridge v. Ludwig-Fonold Mfg. Co., 385 F. Supp. 695 (E.D. Pa. 1974), affd, 517 F.2d 1397 (3d Cir.), cert. denied, 423 U.S. 937 (1975).

$5 \mathrm{Id} .698$.

6 See, e.g., Klein, Enforcement of the Right to Fair Representation: Alternative Forums, in The Duty of Farr Representation 99 (J. McKelvey ed. 1977).

7385 F. Supp. at 698. 
It should be noted at the outset that, although the Supreme Court has made exhaustion of contract-grievance procedures a prerequisite to section 301 actions by individual employees, it has never hinted, even in dictum, that employees should also be required to exhaust intra-union appeals. ${ }^{8}$ Rather, the intra-union exhaustion prerequisite has been developed by lower courts almost entirely through a process of accretion. Some of the "grandfather" cases cited with regularity in support of the requirement contain no discussion or justification at all; ${ }^{9}$ others invoke statutory and judicial policies borrowed from other labor statutes and the law of private associations. ${ }^{10}$

In a number of section 301 cases, for example, courts have concluded that the exhaustion doctrine will stimulate the development of union autonomy and union democracy by encouraging the use of an internal appeals process to resolve internal disputes between the union and its members. ${ }^{11}$ In this vein, many courts have cited liberally the exhaustion proviso in title I of the LaborManagement Reporting and Disclosure Act (LMRDA) ${ }^{12}$ as authority for mandating intra-union exhaustion under section $301 .^{13}$

8 Reliance has, however, been placed upon several Supreme Court decisions by courts invoking the intra-union exhaustion doctrine in $\$ 301$ cases. See, e.g., Vaca v. Sipes, 386 U.S. 171 (1967), cited in McGovern v. Teamsters Local 773, 447 F. Supp. 368 (E.D. Pa.), aff'd, 588 F.2d 821 (3d Cir. 1978), and Pullen v. General Motors Corp., 444 F. Supp. 87, 89 (E.D. Mo. 1978); Glover v. St. Louis-S.F. R. Co., 393 U.S. 324 (1969), cited in Willetts v. Ford Motor Co., 583 F.2d 852, 855 (6th Cir. 1978), and Brookins v. Chrysler Corp., 381 F. Supp. 563, 565 (E.D. Mich. 1974).

9 E.g., Day v. UAW Local 36, 466 F.2d 83 (6th Cir. 1972); Bsharah v. Eltra Corp., 394 F.2d 502 (6th Cir. 1968) (per curiam).

10 E.g., cases cited in notes 82 \& 83 infra. See also Simpson \& Berwick, Exhaustion of Grievance Procedures and the Individual Employee, 51 TEx. L. Rev. 1179 , 1216-19 (1973), for a good discussion of the historical roots of the exhaustion doctrine.

11 E.g., Foy v. Norfolk \& W. Ry., 377 F.2d 243, 246 (4th Cir.), cert. denied, 389 U.S. 848 (1967); Fabian v. Freight Drivers Local 557, 448 F. Supp. 835, 839 (D. Md. 1978); Ratliff v. Ford Motor Co., 98 L.R.R.M. 2699, 2701 (E.D. Mich. 1978); Jenkins v. General Motors Corp., 364 F. Supp. 302, 306 (D. Del. 1973).

12 LMRDA $\$ 101$ (a) (4), 29 U.S.C. $\$ 411$ (a)(4) (1976). See text accompanying notes 96-130 infra for criticism of any reliance upon the exhaustion proviso of title $I$ in $\$ 301$ suits.

19 E.g., Battle v. Clark Equip. Co., 579 F.2d 1338, 1342-43 (7th Cir. 1978); Winter v. Local 639, Int'l Bhd. of Teamsters, 569 F.2d 146, 148 (D.C. Cir. 1977); Thompson v. New York Central R. Co., 250 F. Supp. 175, 176 (S.D.N.Y. 1966) (under Railway Labor Act). Like Thompson, many cases involve claims under the Railway Labor Act, 45 U.S.C. $\$ \$ 151-188$ (1976), rather than under $\$ 301$. E.g., Brady v. Trans World Airlines, Inc., 40I F.2d 87 (3d Cir. 1968), cert. denied, 393 U.S. 1048 (1969); Neal v. System Bd. of Adjustment, 348 F.2d 722 (8th Cir. 1965). The general convergence of the Railway Labor Act and $\$ 301$ of the Labor Management Relations Act has been detailed elsewhere; see Feller, supra note 1, at 676-718. For our purposes, it is sufficient to note that courts have advanced similar rationales in imposing intra-union exhaustion requirements under 
A number of courts have also relied upon provisions in union constitutions that purport to bind members to exhaust internal union appeals before resorting to outside tribunals to obtain relief. ${ }^{14}$ These rationales, however, assume that section 301 controversies are internal union matters and overlook the fact that many employees are not union members.

Intra-union exhaustion is also said to promote the speedy resolution of employee grievances, to aid the conservation of judicial resources, ${ }^{15}$ and to vindicate the federal policy favoring the resolution of labor controversies through private dispute-settlement mechanisms. ${ }^{16}$ In the words of one influential court, the intraunion exhaustion requirement "is bottomed on the hope that [union] procedures will quickly resolve disputes without the delay inherent in the judicial process and with the aid of persons experienced at resolving member-union conflicts short of a full-blown judicial proceeding." 17 These arguments assume again that section 301 disputes arise out of the member-union relationship; they also assume that union tribunals are expert in resolving such disputes and have the means to provide a remedy to the employee's grievance.

Standing alone, the objectives cited in support of intra-union exhaustion are unimpeachable. The question is not, however, whether they are worthy objectives, but rather whether application of the intra-union exhaustion doctrine in fact promotes them. This is an empirical question, rather than one of judicial policy. This Article analyzes the justifications offered in support of the intraunion exhaustion requirement and explores the many and complex empirical considerations that have been overlooked. A full appreciation of the facts and the law leads to the inescapable conclusion that judicial imposition of an intra-union exhaustion requirement on section 301 plaintiffs is ill-conceived and, in most cases, totally unsupportable. In part $\mathrm{I}$, we will evaluate the arguments offered by the courts in support of their extension of the intra-union ex-

the two statutes and have cited Railway Labor Act cases in actions under $\$ 301$. See, e.g., Chambers v. Local 639, Int'l Bhd. of Teamsters, 578 F.2d 375, 384, 387 (D.C. Cir. 1978), citing Neal and Brady. Involvement of claims under the Railway Labor Act will be noted parenthetically.

14 E.g., Newgent v. Modine Mfg. Co., 495 F.2d 919, 927 (7th Cir. 1974); Neal v. System Bd. of Adjustment, 348 F.2d 722, 726 (8th Cir. 1965) (under Railway Labor Act); Manica v. Chrysler Corp., 97 L.R.R.M. 2679, 2681 (E.D. Mich. 1978).

15 E.g., Imel v. Zohn Mfg. Co., 481 F.2d 181, 183-84 (10th Cir. 1973), cert. denied, 415 U.S. 915 (1974); Brady v. Trans World Airlines, Inc., 401 F.2d 87, 104 (3d Cir. 1968), cert. denied, 393 U.S. 1048 (1969) (under Railway Labor Act). 16 E.g., Orphan v. Furnco Constr. Corp., 466 F.2d 795, 801 (7th Cir. 1972);

Brookins v. Chrysler Corp., 381 F. Supp. 563, 569 (E.D. Mich. 1974). 17 Ruzicka v. General Motors Corp., 523 F.2d 306, 312 (6th Cir. 1975). 
haustion doctrine to section 301 litigation, concluding that the exhaustion requirement fails in fact to serve the alleged interests of employees, courts, unions, or employers. Part II will address a rare instance in which application of the intra-union exhaustion requirement to section 301 litigation might still be justified, and will then offer a brief procedural framework for such limited application. In the final part, we will explore the difficulties which would continue to plague courts that require exhaustion even in the narrow circumstances described in part II, difficulties which argue, therefore, for total abandonment of the intra-union exhaustion doctrine in the section 301 setting.

\section{The General Impropriety of Application of the INTRA-Union Exhaustion Doctrine to Section 301 Litigation}

\section{A. The Section 301 Suit in Perspective}

The crucial question explored in this part is whether the requirement that aggrieved employees exhaust intra-union remedies prior to initiating section 301 litigation in fact promotes any legitimate policies. First, however, it is important to understand the basic legal principles involved in a section 301 suit.

Section 301 authorizes "[s]uits for violation of contracts between an employer and a labor organization." 18 Although other parties may also initiate litigation under the section, ${ }^{19}$ this Article is concerned only with actions by individual workers against their employers, actions which seek to vindicate their "uniquely personal rights" created by collective bargaining agreements. ${ }^{20}$ These personal rights-including wage and seniority rights and the right not to be discharged without just cause-are owed by the employer to the employees as individuals. The employee's principal complaint in section 301 litigation is always the employer's alleged breach of contract. To be sure, the union has also presumably injured him by its failure to secure relief for him pursuant to the grievance machinery customarily provided in the collective bargaining agreement. Nevertheless, in most cases only the employer can provide the employee with the full remedy he seeks; the employee's primary dispute is with his employer, not with his union.

18 Labor Management Relations Act $\$ 301$ (a), 29 U.S.C. $\$ 185$ (a) (1976).

19 See, e.g., UAW v. Hoosier Cardinal Corp., 383 U.S. 696 (1966) (recognizing union's standing to assert under $\$ 301$ the rights of individuals it represents).

20 Hines v. Anchor Motor Freight, Inc., 424 U.S. 554, 562 (1976). The line of cases in which the Supreme Court has recognized the individual employee's right to bring $\$ 301$ actions against his employer includes Vaca v. Sipes, 386 U.S. 171 (1967); Humphrey v. Moore, 375 U.S. 335 (1964); and Smith v. Evening News Ass'n, 371 U.S. 195 (1962). 
The union's role in the section 301 action stems from a tension in the law. Section 301 provides for judicial enforcement of the collective bargaining agreement, but Congress has also declared a preference for the settlement of contract disputes through grievance procedures established by the parties. ${ }^{21}$ If section 301 plaintiffs could proceed directly into court, this preference for private settlement would be undermined and the courts would be inundated with section 301 actions. As a result, the Supreme Court has molded a body of decisional law to accommodate the roles of private settlement and formal adjudication and has introduced unfair union representation as a threshold requirement for judicial review.

In the Steelworkers Trilogy, ${ }^{22}$ the Supreme Court limited the role of the judiciary to determining whether grievances are arbitrable. Only if no arbitration procedure covers the dispute in question can the courts decide a case on its merits. If arbitration is available, a court can only require the parties to arbitrate, and it then can enforce arbitral awards. Thereafter, in Republic Steel Corp. v. Maddox, ${ }^{23}$ the Court extended the Trilogy logic to section 301 suits initiated by individual employees and imposed the requirement that employees exhaust their remedies under the contract grievance machinery before bringing suit. Because most unions exercise exclusive control over contract grievance processing, however, unlimited judicial deference to the results would leave the employee vulnerable to arbitrary union conduct. Therefore, in Vaca $v$. Sipes, ${ }^{24}$ the Court held that an employee should be excused from this exhaustion requirement when he can show that the union violated its "duty of fair representation" 25 in its handling of his

21 Labor Management Relations Act $\$ 173(\mathrm{~d})$ (1976) provides inter alia: "Final adjustment by a method agreed upon by the parties is hereby declared to be the desirable method for settlement of grievance disputes . . . ."

22 United Steelworkers v. Enterprise Wheel \& Car Corp., 363 U.S. 593 (1960); United Steelworkers v. Warrior \& Gulf Navigation Co., 363 U.S. 574 (1960); United Steelworkers v. American Mfg. Co., 363 U.S. 564 (1960).

23379 U.S. 650 (1965).

24386 U.S. 171 (1967).

25 The "duty of fair representation" was developed by the Supreme Court over many years. See, e.g., Humphrey v. Moore, 375 U.S. 335 (1964); Ford Motor Co. v. Huffman, 345 U.S. 330 (1953); Steele v. Louisville \& N.R. Co., 323 U.S. 192 (1944) (under Railway Labor Act). The obligation was necessitated by $\$ 9$ of the National Labor Relations Act, 29 U.S.C. $\$ 159$ (1976), which grants unions exclusive representative status for all bargaining-unit employees and, consequently, renders the employees vulnerable to arbitrary union conduct. The duty of fair representation was designed to serve as a "bulwark to prevent arbitrary union conduct against individuals stripped of traditional forms of redress by the provisions of federal labor law." Vaca v. Sipes, 386 U.S. at 182 . Thus, although this duty is not explicitly provided by statute, it is generally said to be statutory in origin and nature. Id. 193. See generally Clark, The Duty of Fair Representation: A Theoretical Structure, 51 TEx. L. Rev. 1119 (1973); Cox, The Duty 
grievance. And finally, in Hines v. Anchor Motor Freight, Inc., ${ }^{26}$ the Court extended Vaca to situations in which the union has processed the employee's claim through the final step of the grievance procedure, ruling that when an employee can show that his union breached its duty of fair representation, judicial deference to the arbitral award pursuant to the Trilogy is inappropriate.

As a result, the typical section 301 action brought by an individual employee has two tiers: the employee must first prove that his union acted wrongfully in processing, or failing to process, his grievance, and only then may he present his contract claim against the employer. The unfair-representation claim plays a distinctly subordinate, albeit threshold, role in the litigation: the plaintiff's principal objective in nearly every case is to obtain a hearing of his contract claim. The union is made a party to the action essentially to aid the court in determining the justiciability of that underlying claim. ${ }^{27}$

This is not to say that unions are totally immune from liability to section 301 plaintiffs for their wrongful handling of valid contract grievances. Under the damage formula announced in Vaca, however, the union is liable only to the extent that its misconduct aggravated the original injury caused by the employer's breach of the collective agreement. ${ }^{28}$ Thus, union liability, if any, can be calculated only with reference to the underlying contract claim; indeed, if that claim proves unfounded, the union may escape any liability, though it mishandled the grievance. ${ }^{29}$ Moreover, in prac-

of Fair Representation, 2 VחL. L. REv. 151 (1957); Feller, supra note I; Summers, The Individual Employee's Rights Under the Collective Agreement: What Constitutes Fair Representation?, 126 U. PA. L. Rev. 251 (1977).

26424 U.S. 554 (1976).

27 See Dorn v. Meyers Parking Sys., 395 F. Supp. 779, 783 (E.D. Pa. 1975) ("In such actions, the employee's claim against his union is frequently only a necessary steppingstone, mandated by Vaca $v$. Sipes . . . to an examination of his real grievance, the discharge by the employer"); Harrison v. Arrow Metal Products Corp., 20 Mich. App. 590, 627, 174 N.W.2d 875, 891 (1969) (concurring and dissenting opinion) (despite unfair-representation allegations, the "gravamen" of a section 301 complaint is the employer breach of contract).

28386 U.S. at 197-98.

29 Cf. Kaiser v. Local 83, Int'l Bhd. of Teamsters, 577 F.2d 642 (9th Cir. 1978). In Kaiser, a district court granted an employer's unopposed motion for summary judgment when the plaintiff-employee admitted that his discharge was not based on any of the grounds specified in the collective bargaining agreement as improper. Id. 645. The court also granted summary judgment for the union, apparently accepting the union's contention that it could not have breached its duty of fair representation when it failed to process the plaintiff's unmeritorious grievance. Id. 644. On appeal, the Ninth Circuit reversed the summary judgment granted to the union; it rejected the district court's determination that, as a matter of law, a union cannot be liable under its duty of fair representation if the underlying claim against the employer is without merit. Holding also that neither an employer nor a union is an indispensable party in an action against the other by 
tice, the contribution of union misconduct to section 301 damages is generally judged to be relatively small. Unfair representation in the section 301 action is therefore nothing more than a screening device, a standard for determining "under what circumstances the individual employee may obtain judicial review of his breach-ofcontract claim despite his failure to secure relief through the contractual remedial procedures." 30

The role of the duty of fair representation in section 301 litigation thus sets it clearly apart from other union obligations which fall under the general heading of "duty of fair representation." Consider, for example, the duty that attaches when a union negotiates, rather than administers, a collective bargaining agreement. Unfair representation in contract negotiations involves misconduct only by the union; the employer has violated no legal duty. In such situations, responsibility for providing aggrieved employees with a remedy should fall primarily, if not exclusively, upon the union; in contrast to the typical section 301 suit, the main dispute is between the individual employee and his union bargaining agent, rather than between the employee and the employer. ${ }^{31}$ This fundamental distinction has been completely overlooked by courts which have invoked the intra-union exhaustion doctrine. We note it here only to emphasize the unique and subordinate role that unfair-representation claims customarily play in section 301 suits by individual workers to remedy employer violations of contract.

Against this background of a complex, two-tiered action for breach of the collective bargaining agreement, we turn now to the question whether the policies cited by the courts to support the intra-union exhaustion doctrine are, in fact, promoted by its application. We first consider those benefits said to flow to the courts and plaintiffs and then address those relevant to union and employer interests.

an employee-union member, the Ninth Circuit remanded for trial of the issue whether the union breached its duty of fair representation. It is at least theoretically possible, then, for the union to breach its duty even though the employer has not violated the contract-that is, the union can handle an unmeritorious grievance in an arbitrary manner. If, however, we accept the Vaca formula which measures a union's liability by its aggravation of a preexisting injury, it is difficult to perceive what relief could be awarded. See note 85 infra.

30 Vaca v. Sipes, 386 U.S. at 185.

31 See, e.g., Battle v. Clark Equip. Co., 579 F.2d 1338 (7th Cir. 1978); Brady v. Trans World Airlines, Inc., 401 F.2d 87 ( $3 \mathrm{~d}$ Cir. 1968), cert. denied, 393 U.S. 1048 (1969) (under Railway Labor Act); Steele v. Brewery \& Soft Drink Local 1162, 432 F. Supp. 369 (N.D. Ind. 1977).

Another variety of unfair representation distinguishable from that in section 301 litigation involves a union's use of agency-shop fees for political purposes. See, e.g., Reid v. UAW, District Lodge 1083, 479 F.2d 517 (10th Cir.), cert. denied, 414 U.S. 1076 (1973). 


\section{B. Putative Benefits of Intra-Union Exhaustion to Employees and Courts}

The requirement that intra-union appeals be exhausted supposedly serves the interests of both individual employees and the courts because "such procedures will quickly resolve disputes without the delay inherent in the judicial process and with the aid of persons experienced at resolving member-union conflicts short of a full-blown judicial proceeding:" 32 Moreover, exhaustion ostensibly permits the courts to avoid committing judicial resources in a field in which others are said to possess expertise. ${ }^{33}$ But, dissecting these claims of benefit, we can ask:

1. Do intra-union appeals offer prompt relief?

2. Can intra-union appeals resolve disputes and afford complete relief, thus eliminating the need for subsequent litigation?

3. Can intra-union appeals afford partial relief, thereby facilitating subsequent judicial disposition?

Let us examine each question in turn.

\section{Offer of Prompt Relief}

Most intra-union appeals procedures involve a series of steps: an appearance before the local-union executive board, a committee, or the whole membership of the local; review by one or more intermediate authorities; and a final appeal to the union's constitutional convention. This process can drag on for years, particularly when appeals must be taken to conventions which may be held as infrequently as once every five years ${ }^{34}$ and are rarely held more often than once every two or three years. ${ }^{35}$ Nonetheless, these delays

32 Ruzicka v. General Motors Corp., 523 F.2d 306, 312 (6th Cir. 1975).

33 Id.

34 See, e.g., Constitution and Bylaws of the International Brotherhood of Teamsters, art. III, $\$ 1$ (adopted in June 1976). The five-year maximum interval between conventions can be explained in part by reference to title IV of the LMRDA, which requires the election of national or international union officers no less often. LMRDA $\$ 401(\mathrm{a}), 29$ U.S.C. $\$ 481(\mathrm{a})$ (1976). Thus, if officers are elected at conventions rather than by referenda, conventions must be held at least every fifth year.

35 A sampling of union constitutions in effect in early 1979 reveals the following intervals between conventions: Constitution \& Bylaws of the International Brotherhood of Teamsters, art. III, $\$ 1$ (adopted in June 1976) (5 years); Constitution of the International Brotherhood of Electrical Workers, art. II, \& I (as amended Sept. 1974) (4 years); Constitution of the Wood, Wire and Metal Lathers International Union, $\$ 204$ (Oct. 1976) (3 years); Constitution of United Steel- 
have not discouraged the courts from invoking the intra-union exhaustion doctrine to dismiss section 301 actions. ${ }^{36}$

The delay involved in the appeals procedure could be reduced if the courts were willing to accept something less than complete exhaustion of intra-union appeals. Indeed, some courts in section 301 cases have held that, if the union has had a reasonable opportunity to respond to the charge of unfair representation, plaintiffs need only attempt to secure a union remedy rather than pursue every formal procedure. ${ }^{37}$ Generally, however, there are no courtimposed time limits: "[E]very available remedy within the labor organization must be exhausted by members before the aid of the courts can be invoked . . . " 38 Although several courts have elected to hear section 301 suits when the plaintiffs had spent years attempting unsuccessfully to secure relief through intra-union channels, ${ }^{39}$ no guidelines have emerged to assist employees in determining when they may safely abandon their union appeals in favor of section 301 adjudication by the courts. As a result, employees wondering how long to pursue intra-union appeals are well advised to persevere until every appellate procedure specified in the union constitution has been exhausted.

The absence of any time limit on the exhaustion requirement is particularly curious given the four-month time limit for exhausting intra-union appeals contained in the LMRDA title I exhaustion

workers, art. VI, $\$ 1$ (adopted in Sept. 1976) (2 years); Constitution of the Oil, Chemical and Atomic Workers, art. III, $\$ 2$ (adcpted in Aug. 1977) (2 years); Constitution of the Communications Workers of America, art. VIII, $\$ 1$ (as amended June 1977) ( 1 year). The United Autoworkers convention appeals committee meets semiannually. Constitution of the International Union, UAW, art. 33, 88 (adopted in May 1977).

36 E.g., Ditzler v. International Ass'n of Machinists Local Lodge No. 1984, 453 F. Supp. 50, 52 (E.D. Pa. 1978).

37 See, e.g., Goclowski v. Penn Central Transp., 571 F.2d 747 (3rd Cir. 1977) (formal procedures not mandatory if informal efforts sufficient to demonstrate futility); Ruzicka v. General Motors Corp., 523 F.2d 306 (6th Cir. 1975) (diligent processing of intra-union proceedings for 27 months sufficient); Gray v. International Ass'n Heat \& Frost Insulators Workers Local 51, 447 F.2d 1118 (6th Cir. 1971) (plaintiff confronted union president at monthly meeting and was told he had no grounds to press charges; plaintiff then pressed grievance through letters to local and international union; sufficient to excuse exhaustion). But see Morin v. General Motors Corp., 91 L.R.R.M. 2578 (E.D. Mich. 1976) (informal letterwriting campaign to union officials over period of five years not sufficient to excuse exhaustion of formal intra-union remedies). See note 67 infra.

38 Foley v. Chrysler Corp., 78 L.R.R.M. 2744 (S.D. Ind. 1971). In Anderson v. Ford Motor Co., 319 F. Supp. 134 (E.D. Mich. 1970), and Cacavas v. General Motors Corp., 77 L.R.R.M. 2841 (Mich. Ct. App. 1968), the plaintiffs' complaints were dismissed for failure to appeal to the union convention before fling suit though they had pursued their intra-union appeals unsuccessfully through the UAW executive board and the public review board.

39 See cases cited in note 37 supra. 
proviso, ${ }^{40}$ which is frequently cited as authority for dismissing section 301 actions. With the exception of dictum in several opinions, courts have not recognized this time limit. ${ }^{41}$ Moreover, although the title I exhaustion requirement is permissive and, indeed, is frequently waived by courts handling LMRDA disputes, ${ }^{42}$ exhaustion is generally said to be mandatory in the section 301 context.43

As one court has observed, "the most frequent result of this additional exhaustion requirement may unfortunately be the 'exhaustion' of deserving employees before they are able to obtain judicial relief." 44 Indeed, the courts that have applied the intraunion exhaustion doctrine to dismiss section 301 suits regrettably have ignored the possibility that the relevant statute of limitations for filing such actions ${ }^{45}$ may lapse while union appeals are being

40 LMRDA $\$ 101(\mathrm{a})(4), 29$ U.S.C. $\$ 411$ (a)(4) (1976):

No labor organization shall limit the right of any member thereof to institute an action in any court, or in a proceeding before any administrative agency, irrespective of whether or not the labor organization or its officers are named as defendants or respondents in such action or proceeding, or the right of any member of a labor organization to appear as a witness in any judicial, administrative, or legislative proceeding, or to petition any legislature or to communicate with any legislator: Provided, That any such member may be required to exhaust reasonable hearing procedures (but not to exceed a four-month lapse of time) within such organization, before instituting legal or administrative proceedings against such organizations or any officer thereof ....

See text accompanying notes 96-130 infra for a discussion of the propriety of reliance on the exhaustion proviso in $\$ 301$ litigation.

41 See, e.g., Battle v. Clark Equip. Co., 579 F.2d 1338, 1343 (7th Cir. 1978); Larimer v. United Inter-Mountain Tel. Co., 428 F. Supp. 8, 12 (E.D. Tenn. 1976); Jenkins v. General Motors Corp., 364 F. Supp. 302, 308 (D. Del. 1973); Thompson v. New York Central R. Co., 250 F. Supp. 175, 176 (S.D.N.Y. 1966) (under Railway Labor Act).

42 See NLRB v. Industrial Union of Marine \& Shipbuilding Workers, 391 U.S. 418, 426 (1968); Chambers v. Local 639, Int'l Bhd. of Teamsters, 578 F.2d 375, 385-86 (D.C. Cir. 1978).

43 Compare the difference in approach and result in Semancik v. UMW District 5, 466 F.2d 144 (3d Cir. 1972); McCraw v. United Ass'n of Journeymen, 341 F.2d 705 (6th Cir. 1965), and Detroy v. American Guild of Variety Artists, 286 F.2d 75 (2d Cir. 1961), all cases involving Title I rights, with cases arising under $\$ 301$, e.g., Baldini v. Local 1095, UAW, 581 F.2d 145 (7th Cir. 1978); Neipert v. Arthur G. McKee \& Co., 448 F. Supp. 206 (E.D. Pa. 1978); and Harrington v. Chrysler Corp., 303 F. Supp. 495 (E.D. Mich. 1969).

44 Dorn v. Meyers Parking Sys., 395 F. Supp. 779, 783 (E.D. Pa. 1975). Cf. NLRB v. Industrial Union of Marine \& Shipbuilding Workers, 391 U.S. 418, 425 (1968) (no justification for making public processes wait until union member exhausts inadequate internal procedures).

45 See UAW v. Hoosier Cardinal Corp., 383 U.S. 696 (1966) (timeliness of a section 301 suit is to be determined, as a matter of federal law, by reference to the appropriate state statute of limitations); Note, Statutes of Limitations Governing Fair Representation Action Against Union When Brought With Section 301 Action Against Employer, 44 Geo. WAst. L. Rev. 418 (1976). 
pursued. ${ }^{46}$ Should the statutory period expire during the appeals process, the judicially imposed exhaustion requirement would not simply delay the section 301 plaintiff, but deprive him of his right to sue. Perhaps the courts' equitable power to toll the statute of limitations pending appeal within the union could be invoked to avoid this harsh result, ${ }^{47}$ but one would think that a medicine with side effects severe enough to cause the patient's demise would be prescribed with greater care.

The disadvantages of the delay that accompanies exhaustion of intra-union appeals of course might be offset by advantages. For example, if union appeals could resolve the dispute and fully compensate the aggrieved employee in no less time than a federal district court would require to afford relief, there might be a valid reason for requiring exhaustion of union remedies. Hence, we turn our attention to this possibility, mindful that if intra-union appeals cannot afford complete relief, section 301 litigation will still be necessary. Should complete relief be unavailable, application of the intra-union exhaustion doctrine would actually postpone, rather than expedite, final resolution of the employee's section 301 controversy.

\section{Avoidance of Litigation by Affording Complete Relief}

Our analysis of this issue will assume that the contract grievance procedure can no longer be reactivated to consider and resolve the employee's dispute, either because the contract statute of limitations has run or because the procedure has already yielded a "final"

46 The courts disagree about whether a tort or contract statute of limitations should apply in a section 301 action in which the union and employer are joined as defendants. See, e.g., Butler v. Local 823, Int'l Bhd. of Teamsters, 514 F.2d 442, 448 (8th Cir.), cert. denied, 423 U.S. 924 (1975) (Missouri five-year contract statute of limitations adopted); Sanderson v. Ford Motor Co., 483 F.2d 102, 114 (5th Cir. 1973) (Alabama's one-year tort statute of limitations adopted); Smart v. Ellis Trucking Co., 409 F. Supp. 129, 132 (E.D. Mich. 1976), aff'd, 580 F.2d 215 (6th Cir. 1978), cert. denied, 440 U.S. 958 (1979) (Michigan three-year tort statute of limitations adopted). A number of courts have found that the applicable statute of limitations is that governing actions for violation of rights created by statute (often three years). E.g., Price v. Southern Pac. Transp., 586 F.2d 750 (9th Cir. 1978) (under Railway Labor Act). When employees have sought, however, to upset final arbitral awards under Hines v. Anchor Motor Freight, Inc., 424 U.S. 554 (1976), on the ground that the union breached its duty of fair representation in prosecuting the grievance, some courts have applied a 90-day statute of limitations found in arbitration statutes. E.g., Wallace v. A.T.\&T., 460 F. Supp. 755 (E.D.N.Y. 1978).

47 See Pesola v. Inland Tool \& Mfg., Inc., 423 F. Supp. 30 (E.D. Mich. 1976) (statute of limitations tolled during pendency of intra-union appeal); $c f$. Jenkins v. General Motors Corp., 364 F. Supp. 302, 309 n.10 (D. Del. 1973) (stay would be of no avail). But see Morin v. General Motors Corp., 91 L.R.R.M. 2578 (E.D. Mich. 1976) (plaintiff's argument that statute of limitations should have been tolled during period in which he attempted to exhaust union appeals rejected). 
decision. ${ }^{48}$ Indeed, this is a legitimate assumption because most contracts contain fairly rigorous time limits for initiating and processing grievances.99 Normally, these limits will have expired long before the employee hires a lawyer and initiates a section 301 action. In such circumstances, we must ask whether the union itself can, or is likely to, provide the employee with complete relief. To answer this question, we must focus upon both the nature and amount of the relief sought and the authority of the union tribunal.

Nearly all union constitutions provide for some appeal from decisions at lower levels of the union hierarchy. However, just as contract grievance machinery is designed to resolve disputes arising under collective bargaining agreements, union appeals procedures are designed to settle disputes arising under the union constitution and bylaws. Typically, these disputes involve the discipline of a member for allegedly violating certain obligations owed to the union as a political institution, such as the duty to pay dues, to conduct oneself responsibly at meetings, or to honor no-strike commitments or authorized picket lines. Most union tribunals are limited to imposing sanctions, such as reprimand, fine, suspension, or expulsion, against offending members; they are powerless to award relief in favor of injured members. ${ }^{50}$ The appeals procedure is designed to protect, and the sanctions to benefit, the union, rather than any member or group of members. Fines are customarily payable to the union treasury, and few union constitutions authorize

48 See text accompanying notes 138-145 infra for a discussion of the exceptional case in which the contract grievance procedure can be reactivated.

49 Feller, supra note 1 , at 752 (footnote omitted):

The time for initiation of ordinary grievances usually ranges from two days to two months; in discharge cases the normal limits vary from one day to a week. Time limits for appealing may be provided at the intermediate steps .... The most typical penalty for failure to meet the time limits is, in the case of initial filing, that the grievance shall not be considered at all, and at the subsequent steps, that it shall be deemed settled on the basis of management's response at the previous step.

See also Baldini v. Local 1095, UAW, 435 F. Supp. 264 (N.D. Ind.), affd, 581 F.2d 145 (7th Cir. 1978) (arbitration request must be filed within 15 days of decision at third step of grievance procedure); White v. Remsco Management, Inc., 91 L.R.R.M. 2647 (E.D. Mo. 1976) (one working day to grieve discharge); Dorn v. Meyers Parking Sys., 395 F. Supp. 779, 786 (E.D. Pa. 1975) (ten days to file written request for arbitration).

Clearly, if the contract statute of limitations has not already run at the time the employee learns that his grievance has been withdrawn or dropped, it will almost certainly have run by the time an intra-union appeal has been heard, not to mention the time required to exhaust all union appeals.

50 See Orphan v. Furnco Constr. Corp., 466 F.2d 795, 801 (7th Cir. 1972). In contrast, when officers of a local union are found to have abused their official responsibilities to the union or its members, the discipline most often meted out is removal from office or imposition of trusteeship by an officer or tribunal of the national union. 
appeals tribunals to award money damages to individual members from the union treasury. ${ }^{51}$

Rarely have courts in section 301 cases bothered to scrutinize the intra-union appeals process before finding exhausion of the process a prerequisite to filing suit. Generally, the courts have been satisfied by the mere existence of some procedure in the union constitution for appealing decisions by local officials. Indeed, some courts have even been content to rely upon findings by other courts that such procedures exist. ${ }^{52}$ In a welcome exception, the Seventh Circuit, in Orphan v. Furnco Construction Corp., ${ }^{53}$ reversed a district-court dismissal for failure to exhaust intra-union procedures after concluding that the constitution of the Bricklayers and Stone Masons provided only for "criminal-type prosecutions against Union members and officers"-prosecutions designed to impose penalties upon the guilty, not to afford relief to the injured. ${ }^{54}$ Thus, the court in Orphan reasoned, it was not a procedure that "so certainly holds out the prospect of . . . relief that the plaintiffs could justifiably be expected to have recourse to it before filing suit." 55 In fact, the internal procedures of most unions differ very little from those of the Bricklayers, ${ }^{58}$ but the Orphan decision remains, for the

51 Cf. Winter v. Local 639, Int'l Bhd. of Teamsters, 569 F.2d 146 (D.C. Cir. 1977) (court recognized that Teamster tribunals could not award money damages but found that they could grant type of specific relief sought, an order that union process grievances in nondiscriminatory fashion in future).

52 E.g., Ditzler v. International Ass'n of Machinists Local 1984, 453 F. Supp. 50, 52 (E.D. Pa. 1978), citing Brady v. Trans World Airlines, Inc., 401 F.2d 87, 104 n.57 (3d Cir. 1968), cert. denied, 393 U.S. 1048 (1969) (under Railway Labor Act), which, in turn, had relied upon International Ass'n of Machinists v. Friedman, 252 F.2d 846 (D.C. Cir.), cert. denied, 357 U.S. 926 (1958), for the proposition that the appeals procedures of the IAM were adequate. See also Neal v. System Bd. of Adjustment, 348 F.2d 722, 726 (8th Cir. 1965) (under Railway Labor Act) (Railway Clerks' procedures); Fabian v. Freight Drivers Local 557, 448 F. Supp. 835, 839 (D. Md. 1978) (Teamster procedures). But see Deboles v. Trans World Airlines, Inc., 350 F. Supp. 1274, I290 (E.D. Pa. 1972) (under Railway Labor Act), in which the court found the IAM procedure "completely shrouded in the discretionary power of the Union, the actual party against whom the real complaint is made."

53466 F.2d 795 (7th Cir. 1972).

54 Id. 801 .

55 Id. Contra, Ruzicka v. General Motors Corp., 523 F.2d 306, 311 (6th Cir. 1975) ("intra-Union remedies are part and parcel of the industrial in-house procedure for settling labor disputes"). This finding by the Sixth Circuit was based neither upon cited authority nor on an investigation by the court into the procedures or remedies available within unions.

56 See, e.g., Constitution \& Bylaws of the International Brotherhood of Teamsters, art. XIX (adopted in June 1976), particularly its "relief" provision, $\$ 9(a)$, which reads:

Decisions and penalties imposed upon individual members, officers, elected Business Agents, Local Unions, Joint Councils or other subordinate bodies found guilty of charges may consist of reprimands, fines, suspensions, ex- 
most part, atypical. This does not, however, prevent union counsel from attempting to derail the member's suit with creative interpretations of the union constitution which may never have been adopted or applied by the union or its appeals tribunals. ${ }^{57}$

Even if we assume that unions are constitutionally authorized to do more than just fine, suspend, or expel "guilty" members, that they can actually award an aggrieved member monetary relief, they would still be unable to eliminate the need for subsequent judicial proceedings in section 301 actions. First, money damages for lost pay are but one form of relief normally sought by section 301 plaintiffs. An unjustly terminated employee may also seek reinstatement to his job, or an employee improperly denied his seniority may seek to have it restored. Only the employer can provide such specific or injunctive relief, and once the contract statute of limitations has run, only the courts can satisfy these claims. When such claims are involved, the employee must proceed to court regardless of what the union does.

Even assuming that the employee's claim could be satisfied by a damage award, however, subsequent litigation against the employer could be avoided only if a union were willing to pick up the entire tab and thus bear the burden of the employer's liability as well as its own. Most unions, however, have exceedingly tight budgets which do not allow for the payment of sizable damage awards. Of course, a union might conceivably agree to bear this burden if a

pulsions, revocations, denial to hold any office permanently or for a fixed period or commands to do or perform, or refrain from doing or performing, specified acts.

Courts have recognized that the Teamsters' constitution does not permit union tribunals to award damages for unfair representation. See Miller v. Gateway Transp. Co., 103 L.R.R.M. 2591, 2593 \& n.4 (7th Cir. 1980); Winter v. Local 639, Int'l Bhd. of Teamsters, 569 F.2d 146, 149, 151 n.26 (D.C. Cir. 1977); Fabian v. Freight Drivers Local 557, 448 F. Supp. 835, 839 (D. Md. 1978). In Miller, the district court had granted summary judgment in favor of both the union and the employer on the ground that Miller had failed to exhaust first his internal union remedies. Because Miller's appeal from the grant of summary judgment for the union was dismissed by the court of appeals as untimely, however, only the judgment in favor of the employer was actually before the court. Although these circumstances certainly limit what may properly be considered the court's holding, in fact the court found a review of the relief available from the union essential to its disposition of the suit against the employer.

See also IBEW Constitution, art. XXVII, $\$ 1$ (as amended Sept. 1974); Constitution of the Oil, Chemical and Atomic Workers, art. XII, $\$ 1$ (adopted in Aug. 1977); Constitution of United Steelworkers, art. XII, $\$ \$ 1,2$ (adopted in Sept. 1976).

57 In Lucas v. Philco-Ford Corp., 380 F. Supp. 139 (E.D. Pa. 1974), for example, counsel for the International Union of Electricians argued, albeit unsuccessfully in this instance, that "a fine levied against the offending party or parties in an amount payable to plaintiff in order to make him 'whole' would [not] be ... beyond the definitional boundaries of the word "discipline." Id. 145 (quoting memorandum of union). 
full settlement would tax its treasury less than the attorney fees it would otherwise incur defending itself in a section 301 action. Aside from this remote possibility, however, it is absurd to suggest that unions would even consider paying for injuries resulting from an employer's breach of contract. As the Supreme Court observed in Vaca v. Sipes, "It could be a real hardship on the union to pay these damages, even if the union were given a right of indemnification against the employer . . . [W] see no merit in requiring the union to pay the employer's share of the damages." 58

Thus, it appears, nearly all aggrieved employees ultimately will be forced into court. Some grievants will be faced immediately with the fact that their union constitution does not authorize the award of monetary damages under even the most creative interpretation by union counsel. In instances in which the union can award money damages, the union's unwillingness or inability to bear the employer's share of the liability-by far, the larger portion -will still necessitate that the employee file a section 301 action to obtain relief from his employer. ${ }^{59}$ Perhaps most important, even if the union could and would award monetary damages for the entire injury, much of his claim may require relief that only a court can provide. ${ }^{60}$ Therefore, application of the intra-union exhaustion doctrine to aggrieved employees seeking damages and injunctive relief from their employers actually delays final adjudication of the employer's potential liability to the employee. The delay may well aggravate the employee's injury, and the damages continue to accrue in the meantime. Neither justice nor judicial economy is promoted.

\section{Facilitation of Disposition of Subsequent Litigation}

Even though intra-union appeals will, in most cases, fail to eliminate entirely the need for judicial proceedings, it still may be asserted that such appeals will contribute to a partial resolution of the section 301 controversy by disposing of the unfair-representation claim. By severing the claim against the union, the court's task is simplified and the aggrieved employee obtains partial relief from the union for its wrongdoing. The employee's claim-at least that part of his claim that concerns the union-will be reviewed, this

5s 386 U.S. 171, 197 (1967) (footnote omitted); Miller v. Gateway Transp. Co., 103 L.R.R.M. 2591, 2593 n.6 (7th Cir. 1980).

59 Indeed, even if a union constitution were to authorize compensation of members injured as a result of officers' constitutional violations, the provision would not nécessarily authorize an award of damages for breach of an officer's statutory duty of fair representation.

60 Lucas v. Philco-Ford Corp., 380 F. Supp. at 145. 
argument assumes, by tribunals with some expertise in resolving such disputes. At best, the court is spared an excursion into areas in which its expertise is limited; at worst, the issues are sharpened, thus simplifying the judicial task. In practice, however, the courts cannot reasonably depend upon, let alone defer to, union tribunals for disposition of unfair-representation allegations.

The probability of bias is an initial reason to doubt the capability of union tribunals to resolve claims of unfair representation. Union tribunals are not detached judicial bodies resolving disputes brought before them according to fixed rules and firm precedents. ${ }^{61}$ They are political bodies composed of union officials, and it is not unfair to say that they will consider the political and financial interests of the union foremost in their disposition of any unfairrepresentation claim. ${ }^{62}$

The first step in most intra-union procedures is an appeal to the local, to the very officials alleged to have mishandled the employee's grievance. Nonetheless, a claim of union hostility or bias at the local level has generally not been sufficient to persuade the courts to excuse failure to exhaust intra-union appeals. ${ }^{63}$ Indeed, even a showing of implacable hostility at the local level may not suffice if the court perceives the possibility of impartial review at another level of the union hierarchy. ${ }^{64}$ As a practical matter, how-

$61 \mathrm{Cf}$. notes $72-75$ infra (possibility of review by impartial tribunal).

62 The political interests of the union can also find expression on the job in direct reprisals against an employee or in withdrawal of union protection. Because the requirement of intra-union exhaustion prolongs the period during which a member may be subject to union hostility without outside impartial support, he may be unwilling to run the gauntlet of intra-union appeals and thus may be discouraged from vindicating his contract rights. Although federal labor policy may favor the private settlement of labor disputes, it surely may not be said to favor effective denial of employee access to the courts. $C f$. Lacy v. Freight Employees Local 667, 99 L.R.R.M. 2403 (W.D. Tenn. 1978), appeal docketed, No. C-74-454 (6th Cir. June 27, 1978) (scheduled for oral argument April 17, 1980) (union fined member $\$ 2000$ as discipline for filing grievances subsequently decided against him and for filing suit against union for unfair representation in which union spent $\$ 1500$ on attorneys' fees); Pawlak v. Greenawalt, 477 F. Supp. 149 (M.D. Pa.), appeal filed, No. 78-1035 (3d Cir. Oct. 12, 1979) (local fined member $\$ 2635$ to recover its costs in defending suit by member).

63 Most courts presume, without inquiry, that review by higher union tribunals will be impartial. For example, in Aldridge v. Ludwig-Honold Mfg. Co., 385 F. Supp. 695 (E.D. Pa. 1974), aff'd, 517 F.2d 1397 (3d Cir.), cert. denied, 423 U.S. 937 (1975), the court simply concluded: "Where, as here, there exist internal procedures providing reasonably prompt review of adverse decisions by union levels higher than those responsible for the decisions, this Court's entertainment of an employee's suit in spite of his failure to utilize these procedures would undercut the policy [favoring non-judicial resolution] ...." Id. 699. See also Harrington v. Chrysler Corp., 303 F. Supp. 495, 497 (E.D. Mich. 1969).

64 E.g., Winter v. Local 639, Int'1 Bhd. of Teamsters, 569 F.2d 146, 149 (D.C. Cir. 1977) ("[t]he cases that have excused failure to exhaust on this ground . . . have involved quite extreme facts. Evidently, in order to prevail on this ground, 
ever, there are likely to be strong ties of interest between local officers and the national union officials who may later be required to evaluate the conduct of their local colleagues. To be sure, the politics in each union differ, and there may even be situations in which national union officials are politically hostile toward local officers whose conduct in processing a grievance is before them on review, but normally the administrators of any organization will unite to resist challenges to their authority posed by outsiders. ${ }^{65}$ Clearly, a claim of unfair representation may appear as just such a challenge. Moreover, in some cases, there may be a political conflict important to the international union underlying the unfairrepresentation claim-for example, when the grievant is a member of an opposition group within the union which management would also like to discourage.

Furthermore, decisions by union tribunals at any level are likely to be tempered by a concern for the union's potential liability as well as by political considerations. Although this form of bias may be less pronounced when national union entities cannot be made to assume and discharge liabilities incurred by locals, one may safely assume that national union officers-a number of whom simultaneously hold office at lower levels of the union-will be reluctant to impose financial liability upon any entity within their union. ${ }^{66}$ Therefore, even when an intra-union appeal may be taken to officials not directly involved in the questioned conduct, it is unwise to presume that bias will not render the appeal futile. ${ }^{67}$

[the plaintiff] must make a specific and convincing showing of union animus") (footnotes omitted). Accord, Pawlak v. Teamsters Local 764, 444 F. Supp. 807, 811 (M.D. Pa. 1977), affd, 571 F.2d 572 (3d Cir. 1978); Brookins v. Chrysler Corp., 381 F. Supp. 563, 566 (E.D. Mich. 1978).

65 This form of prejudice may be eliminated by providing for review by truly impartial individuals or tribunals, such as the United Auto Workers' Public Review Board. Courts have failed to recognize, however, that judicial deference to such impartial arbiters should not be extended to other union tribunals. With few exceptions, the numerous decisions extending the intra-union exhaustion doctrine to litigation involving the UAW have been routinely cited as precedent in cases involving other unions lacking impartial arbitral bodies in their appellate structure. But see text accompanying notes 72-75 infra for a discussion of the difficulties that arise with even impartial tribunals.

66 Typically, union funds are devoted entirely, either directly or indirectly, to providing all members with representation. Most union officers probably perceive the diversion of the union's limited funds to benefit an individual or small group as impairing the union's potential effectiveness and as compromising the collective interests of the membership. See generally IBEW v. Foust, 442 U.S. 42, 48-52 (1979) (under Railway Labor Act).

67 A corollary to the exhaustion doctrine is, of course, that exhaustion will not be excused unless the plaintiff can meet the burden of proving that internal union appeals would be futile. See, e.g., Willetts v. Ford Motor Co., 583 F.2d 852, 855 (6th Cir. 1978); Imel v. Zohn Mfg. Co., 481 F.2d 181, 184-85 (10th Cir. 1973), cert. denied, 415 U.S. 915 (1974); Manica v. Chrysler Corp., 97 L.R.R.M. 2679, 
Also, given the incentives to deny employee appeals challenging the conduct of union officers in processing grievances, union tribunals may well be inclined to cloud or distort the issues, rather than to sharpen them, and to fashion decisions exonerating the union with the expectation of judicial deference should the aggrieved employee later bring suit. Carefully drafted decisions by union tribunals or their skilled legal counsel undoubtedly represent an effective way for unions to protect their interests. Obviously, little judicial credence should be given to the findings or conclusions contained in adverse decisions rendered by union tribunals. ${ }^{68}$

Let us assume for a moment that bias and hostility do not infect the intra-union appeals procedure and that, as a result, this impulse to distort issues is absent. Can courts expect an intra-union appeal to aid their disposition of section 301 actions even in these circumstances? We must recall that the threshold issue raised by the typical section 301 action initiated by an individual employee is whether his union breached its duty of fair representation when processing his grievance. The second issue is whether the employer denied the employee his rights in breach of the collective bargaining agreement. ${ }^{60}$

Clearly, because unions both negotiate and administer labor agreements, they have some expertise in construing the terms of such contracts. On the other hand, it is equally clear that union tribunals do not possess any expertise in determining whether their

2681 (E.D. Mich. 1978); Baldini v. Local 1095, UAW, 435 F. Supp. 264, 268 (N.D. Ind. 1977), aff'd in relevant part, 581 F.2d 145 (7th Cir. 1978); Cubas v. Rapid Am. Corp., 420 F. Supp. 663, 668 (E.D. Pa. 1976). But see Jenkins v. General Motors Corp., 84 L.R.R.M. 2643, 2648 n.10 (D. Del. 1973) (dismissal for failure to exhaust despite "fact that plaintiff appears clearly to have lost his right to pursue his internal union remedies"). Few courts have shifted to the union the burden of proving that its procedures do, in fact, hold out a clear prospect of affording complete relief. See, e.g., Frederickson v. System Fed'n No. 114, 436 F.2d 764, 768 (9th Cir. 1970) (under Railway Labor Act); Dorn v. Meyers Parking Sys., 395 F. Supp. 779, 785-86 (E.D. Pa. 1975). See also Foust v. IBEW, 572 F.2d 710, 716-17 (10th Cir. 1978), rev'd in part on other grounds, 442 U.S. 42 (1979) (under Railway Labor Act); Orphan v. Furnco Constr. Corp., 466 F.2d 795, 801 (7th Cir. 1972); Retana v. Apartment, Motel, Hotel \& Elevator Operators Local 14, 453 F.2d 1018, 1027 (9th Cir. 1972).

08 There remains the distinct possibility that union appeals will not yield reasoned, written opinions. Generally, there are few procedures binding union tribunals and there is no requirement that their decisions be in writing or that their conclusions be supported by findings or analysis. Although a record of the intra-union proceeding might afford some insights, intra-union procedures are generally, and necessarily, informal, and a usable record is rarely produced. In fact, testimony ordinarily is not taken under oath and evidence may be admitted or excluded as the tribunal or presiding officer may see fit. See generally International Bhd. of Boilermakers v. Hardeman, 401 U.S. 233, 244-46 (1971); Ritz v. O’Donnell, 566 F.2d 731 (D.C. Cir. 1977); Pawlak v. Greenawalt, 464 F. Supp. 1265 (M.D. Pa. 1979); Rosario v. Dolgen, 44 I F. Supp. 657 (S.D.N.Y. 1977).

69 See text accompanying notes $22-27$ supra. 
own conduct in processing an employee's grievance may have violated the duty of fair representation. Were that duty one established by the union constitution, the courts might justifiably defer to the union's determination whether the duty has been violated, just as final determination of violations of collective bargaining agreements is normally left to arbitrators. The duty of fair representation is, however, a statutory doctrine, refined by courts, not by unions. That union tribunals are more qualified than courts to construe public law or to apply a preeminently judicial doctrine is patently incorrect. ${ }^{70}$ Indeed, the Supreme Court has made it clear that "the courts are . . . the primary guardians of the duty of fair representation." 71

Unions might, of course, structure their appeals process to include review by a board of impartial outsiders, including lawyers or jurists with a substantial understanding of the duty of fair representation. The United Auto Workers has attempted this with its public review board. Even so, before giving decisions by such tribunals any weight, the courts should assure themselves that the standard of fair representation applied by such tribunals matches the duty defined by the judiciary. Indeed, decisions of the UAW Public Review Board are defective in precisely this respect. David Klein, counsel to the review board, has acknowledged that its jurisdiction is limited to those unfair-representation claims which allege bad faith. ${ }^{72}$ The judicially recognized standard is not nearly so confined..$^{73}$ Thus, although nearly fifty percent of the reported decisions requiring employees to exhaust intra-union appeals have involved auto workers, ${ }^{74}$ given the limited jurisdiction of the review board, little or no judicial weight can ultimately be assigned to its decisions rejecting unfair-representation claims. ${ }^{75}$

70 See Alexander v. Gardner-Denver Co., 415 U.S. 36, 58 n.19 (1974) (union and employee interests not always harmonious; union's exclusive control over grievance procedure of concern); Lucas v. Philco-Ford Corp., 380 F. Supp. 139, 145 (E.D. Pa. 1974) (claim against union for breach of duty of fair representation can only be resolved in court of law). See note 25 supra for a discussion of the origins of the duty of fair representation.

71 Czosek v. O'Mara, 397 U.S. 25, 27 (1970).

72 Klein, supra note 6, at 99. See Harrison v. Arrow Metal Prod. Corp., 20 Mich. App. 590, 624, 174 N.W.2d 875, 892 (1969) (concurring and dissenting opinion).

${ }^{73}$ See Vaca v. Sipes, 386 U.S. 171, 190-91 (1967) ("arbitrary" or "perfunctory" handling of grievances contsitutes breach of the duty of fair representation); Ruzicka v. General Motors Corp., 523 F.2d 306, 310 (6th Cir. 1975) ("negligent" handling of grievances subjects union to liability for breach of duty); Klein, supra note 6 , at 99 .

74 Authors' estimate.

75 Cf. Ruggirello v. Ford Motor Co., 411 F. Supp. 758 (E.D. Mich. 1976) (court ordered terminated employee to exhaust UAW appeals procedure, but 
Indeed, the public review board may in one respect present an unusually favorable picture of union-tribunal handling of unfairrepresentation claims. Its narrow definition of the duty of fair representation has been acknowledged, and its determinations may be evaluated accordingly. Other union tribunals may well follow the review board in regarding the obligation imposed by the union's duty of fair representation as substantially less than that imposed by the courts. But, because most union tribunals keep no records of their proceedings and issue no written decisions, it may be impossible for a court to determine what standard of duty was applied. $^{76}$ It is therefore difficult to perceive how requiring exhaustion of intra-union appeals simplifies the courts' task of reviewing alleged union violations of the duty of fair representation.

Despite these difficulties one may still inquire if intra-union appeals will at least assist the court in determining whether challenged employer conduct was in breach of contract. The answer is probably not. First, conduct of a union officer processing a member's grievance, not employer conduct, lies at the heart of the intraunion appeal. Although the member might base his claim of unfair representation on an assertion that the employer's conduct was so obviously in breach of contract that the union's refusal to process his grievance was necessarily arbitrary, the union tribunal need not consider the contract claim before finding that the union's action did not give rise to any liability. ${ }^{77}$

On the other hand, any intra-union award for unfair representation presumably must be based on the underlying breach of the collective bargaining agreement. According to the formula for allocating liability between employers and unions announced by the Supreme Court in Vaca v. Sipes, the union is responsible to the

retained jurisdiction in event claims not settled by such means). One may even question whether the courts should require exhaustion of UAW procedures in light of the narrow standard of review and the fact, conceded by David Klein, that in the more than 20 years of the public review board's existence, only one appeal has resulted in a finding of breach of the duty of fair representation. Under such circumstances, the possibility of securing a remedy is so remote that even this most enlightened of all intra-union appellate structures is fatally defective.

76 See note 9 supra.

77 In a related manner, a number of courts have held that a "plaintiff can not establish a breach of duty simply by proving his underlying grievance was meritorious." Cooper v. Westinghouse Elec. Corp., 416 F. Supp. 13, 17 (S.D. Ind. 1976). See, e.g., Woods v. North Am. Rockwell Corp., 480 F.2d 644, 648 (10th Cir. 1973); Turner v. Air Transp. Dispatchers' Ass'n, 468 F.2d 297, 299 (5th Cir. 1972) (under Railway Labor Act); Thomas v. Ford Motor Co., 396 F. Supp. 52, 57 (E.D. Mich. 1973), aff'd, 516 F.2d 902 (6th Cir.), cert. denied, 421 U.S. 988 (1975). But see Harrison v. United Transp. Union, 530 F.2d 558, 561 (4th Cir.), cert. denied, 425 U.S. 958 (1975) ("proof of a grievance's merit is circumstantial evidence that the failure to process the claim constituted bad faith"). 
aggrieved employee only insofar as its breach of duty aggravated his preexisting injury. ${ }^{78}$ Indirectly, therefore, the intra-union exhaustion doctrine requires the union tribunal to determine whether a breach of contract has occurred because, absent a breach, the union would not be liable for its conduct in violation of the duty of fair representation. Courts cannot, however, expect union tribunals to decide that the employee's underlying grievance was plainly meritorious and, on that basis, to make an award of damages for breach of the duty of fair representation. Rather, this interdependence further assures that the duty of fair representation claim will not be considered on its merits. Imagine a union's chagrin when after awarding damages for a breach of its duty of fair representation, a court later finds that the employer's conduct did not violate the collective bargaining agreement; therefore the union need not have paid a penny. It would be reckless indeed for the union to make an award when the contract claim is in any way questionable. Even when a union has recognized that a breach of the duty of fair representation has occurred, it might seek to avoid the issue by fashioning a self-interested decision upholding the employer's conduct or contract interpretation. Again, it is unlikely that the intra-union appeals process will yield either relief to aggrieved employees or decisions which will sharpen issues for judicial disposition.

Finally, let us suppose, despite all the odds against intra-union appeals decisions in favor of the aggrieved employee, that an employee somehow secures a favorable award. A subsequent judicial proceeding would still probably not be simplified. Once the union tribunal has made its award, the employee would still have to sue under section 301 to seek relief against his employer. Presumably, he still would have to prove unfair representation by his union. The court would then have to decide whether the intra-union award would constitute irrefutable proof of a union breach of the duty of fair representation, a presumption of wrongdoing, or just evidence.

If we pursue this supposition that union tribunals may actually award relief to aggrieved employees, an anomaly emerges. Recall that in the traditional section 301 suit against an employer for breach of contract, the union serves as the first, and often the most formidable, line of defense. Few employees succeed in proving that their union breached its duty of fair representation. If, however, the union could strike a deal with the aggrieved employee by admitting a fair-representation violation in exchange for a nominal 
money award and a release, the union could avoid both potential liability and the inevitable attorney fees it would incur participating actively in a section 301 suit. Armed with the union's admission of wrongdoing, the employee would be able to hurdle the fair-representation obstacle with relative ease and proceed directly against his employer. Union witnesses, generally inclined to testify against section 301 plaintiffs, would appear in court to support the employee's claims. Both employees and their unions would gain an advantage. Finality of the grievance-arbitration process, an underlying objective of the Steelworkers Trilogy and the fair-representation doctrine, would, however, suffer. Unless the courts were to ignore union decisions as untrustworthy, aggrieved employees would regularly be able to obtain judicial review of their contract claims against employers. Given the choice, the courts would undoubtedly opt for de novo consideration of the claim of unfair representation. Moreover, should the intra-union exhaustion doctrine become more firmly entrenched in the section 301 context, the courts will quite possibly be faced with this choice at some point. Should these events come to pass, the intra-union exhaustion doctrine certainly would fall quickly from favor.

In summary, intra-union appeals will not resolve the underlying contractual or statutory dispute and thereby avoid the need for judicial proceedings. Moreover, the courts are likely to find very little in prior intra-union appeals to make their burden of investigation and decision any easier. Indeed, by extending the intraunion exhaustion doctrine to issues arising not under union constitutions, but rather under statute and collective bargaining agreements, the courts may well be undermining the doctrine of finality of the grievance process. This blow to finality will, in turn, impose substantial new burdens on the judiciary and dictate prompt abandonment of the intra-union exhaustion doctrine in section 301 actions.

There remains to evaluate the union and employer interests cited by courts in support of their application of the intra-union exhaustion doctrine to section 301 plaintiffs. Although exhaustion may not resolve the individual plaintiff's dispute, it still might be justified by promoting some other legitimate interests.

\section{G. Putative Benefits of Intra-Union Exhaustion to Unions and Employers}

Courts have invoked both contract and statutory principles designed to protect unions to support their extension of the intra- 
union exhaustion doctrine to section 301 cases. Thus, when the union constitution imposes upon members an obligation to exhaust internal remedies before seeking judicial recourse against the union, some courts have said that the employee is contractually bound to do so. ${ }^{79}$ Indeed, most courts following this contract principle have found that member ignorance of the constitutional exhaustion requirement-even if the requirement is complex or the union has misled the member about it-will not excuse failure to pursue intraunion appeals. ${ }^{80}$ A number of courts have relied in addition upon the exhaustion proviso in title I of the LMRDA ${ }^{81}$ to find that exhaustion of union procedures avoids "judicial interference with the internal affairs of a labor organization until it has had at least some opportunity to resolve disputes concerning its own legitimate affairs." 82 Indeed, it is sometimes said that intra-union exhaustion, even in the section 301 context, promotes the development of democratic union processes and responsible self-government. ${ }^{83}$

Employers, on the other hand, have been found, with one narrow exception, to have no legitimate interest in requiring intraunion exhaustion or in pleading plaintiff's failure to exhaust as a defense. ${ }^{34}$ Although employers are undoubtedly the beneficiaries

79 Neal v. System Bd. of Adjustment, 348 F.2d 722, 726 (8th Cir. 1965) (under Railway Labor Act). Accord, Battle v. Clark Equip. Co., 579 F.2d 1338, 1342-43 (7th Cir. 1978); Winter v. Local 639, Int'l Bhd. of Teamsters, 569 F.2d 146, 150 (D.C. Cir. 1977); Harrison v. Chrysler Corp., 558 F.2d 1273, 1277-78 (7th Cir. 1977); Newgent v. Modine Mfg. Co., 495 F.2d 919, 927-28 (7th Cir. 1974); Imel v. Zohn Mfg. Co., 481 F.2d 181, 184 (10th Cir. 1973), cert. denied, 415 U.S. 915 (1974); Orphan v. Furnco Constr. Corp., 466 F.2d 795, 800-01 (7th Cir. 1972); Manica v. Chrysler Corp., 97 L.R.R.M. 2679, 2681 (E.D. Mich. 1978). Cf. Soto Segarra v. Sea-Land Serv., Inc., 581 F.2d 291, 295 (Ist Cir. 1978) (non-union-member employee not bound by contract to exhaust internal union remedies).

80 Newgent v. Modine Mfg. Co., 495 F.2d 919, 928 (7th Cir. 1974). Accord, Ratliff v. Ford Motor Co., 98 L.R.R.M. 2699, 2701-02 (E.D. Mich. 1978); Pawlak v. Local 764, Int'l Bhd. of Teamsters, 444 F. Supp. 807, 811 (M.D. Pa. 1977), affd, 571 F.2d 572 (3d Cir. 1978); Savel v. Detroit News, 435 F. Supp. 329, 333 (E.D. Mich. 1977); Baldini v. Local 1095, UAW, 435 F. Supp. 264, 267 (N.D. Ind. 1977), aff'd in relevant part, 581 F.2d 145, 148-49 (7th Cir. 1978); Brookins v. Chrysler Corp., 381 F. Supp. 563, 566-67 (E.D. Mich. 1974); see also Jenkins v. General Motors Corp., 364 F. Supp. 302, 309 (D. Del. 1973); Donahue v. Acme Markets, Inc., 62 L.R.R.M. 2770, 2771 (E.D. Pa. 1966).

81 LMRDA \$101(a)(4), 29 U.S.C. $\$ 411(\mathrm{a})(4)$ (1976). For the text of the proviso, see note 40 supra.

82 Brady v. Trans World Airlines, Inc., 401 F.2d 87, 104 (3d Cir. 1968), cest. denied, 393 U.S. 1048 (1969) (under Railway Labor Act).

83 See, e.g., Foy v. Norfolk \& W. Ry., 377 F.2d 243, 246 (4th Cir.), cert. denied, 389 U.S. 848 (1967) (under Railway Labor Act); Fabian v. Freight Drivers Local 557, 448 F. Supp. 835, 839 (D. Md. 1978).

84 Geddes v. Chrysler Corp., 608 F.2d 261, 263-64 (6th Cir. 1979); Fizer v. Safeway Stores, Inc., 586 F.2d 182, 184 (10th Cir. 1978); Winter v. Local 639, Int'l Bhd. of Teamsters, 569 F.2d 146, 150 (D.C. Cir. 1977); Orphan v. Furnco 
of all judicial barriers to the prosecution of section 301 actions, they have bargained only for the utilization of contract grievance machinery and, as a rule, have no standing, to urge a plaintiff's failure to exhaust union-constitutional procedures as a defense in a section 301 action. ${ }^{85}$ The exception, developed by the Seventh Circuit in Harrison v. Chrysler Corp. ${ }^{86}$ permits employers to raise the defense only when they can demonstrate that "an intraunion appeal could result in reversal of the union's refusal to press the grievance and that the grievance could be reinstated in accordance with the provisions of the collective bargaining agreement." 87 We will discuss this exceptional situation further in part II.

Although employer interests in requiring intra-union exhaustion can thus be addressed rather summarily, putative union interests demand closer scrutiny. Much of the discussion of union interest in an internal appeals process focuses on notions of responsible and democratic self-government. As noted when discussing whether employee and judicial interests would be served by requiring intra-union exhaustion, however, responsible union self-government is not likely to emerge; more likely are instances of bias and disingenuous union conduct. ${ }^{88}$ Perhaps discussion of union interests could end with the conclusion that such interest is not in fact served by the exhaustion requirement; there remain, however, the arguments that union members are statutorily required by the LMRDA, and contractually obligated by their union constitutions,

Constr. Corp., 466 F.2d 795, 800-01 \& n.12 (7th Cir. 1972); Petersen v. Rath Packing Co., 461 F.2d 312, 315 (8th Cir. 1972); Retana v. Apartment, Motel, Hotel \& Elevator Operators Local 14, 453 F.2d 1018, 1027 n.16 (9th Cir. 1972). Contra, Brookins v. Chrysler Corp., 381 F. Supp. 563, 568-69 (E.D. Mich. 1974).

85 Simpson and Berwick suggest that, when an employer is not permitted to utilize the defense of failure to exhaust intra-union remedies, plaintiff-employees have an incentive to name only their employers as defendants, thereby undermining the federal policy enunciated in Vaca. Simpson \& Berwick, supra note 10, at 1224 . However, whenever the plaintiff's action relies upon an alleged breach of the union's duty of fair representation, the union would seem to be an indispensable party under rule 19 of the Federal Rules of Civil Procedure. FED. R. Crv. P. 19. Accordingly, the union would have to be joined and federal policy could not be undermined. Neipert v. Arthur G. McKee \& Co., 448 F. Supp. 206, 210 (E.D. Pa. 1978). Contra, Geddes v. Chrysler Corp., 608 F.2d 261 (10th Cir. 1978); Baldini v. Local 1095, UAW, 581 F.2d 145 (7th Cir. 1978); but see Kaiser v. Local 83, Int'l Bhd. of Teamsters, 577 F.2d 642 (9th Cir. 1978) (court stated neither union nor employer an indispensable party; suit continued against union after summary judgment for employer); but cf. Czosek v. O'Mara, 397 U.S. 25, 29 (1970) (damages caused by employer's violation of contract and by union's failure to represent fairly are separate issues).

86558 F.2d 1273 (7th Cir. 1977).

87 Id. 1279. See also Baldini v. Local 1095, UAW, 581 F.2d 145, 149 (7th Cir. 1978); Neipert v. Arthur G. McKee \& Co., 448 F. Supp. 206, 210 (E.D. Pa. 1978).

8s See text accompanying notes 57 \& 61-68 supra. 
to exhaust internal union appeals. Although courts may seem to have abdicated judicial responsibility by failing to explore the adequacy of union remedies and the likelihood of impartial union review even when applying the "futility" exception, ${ }^{89}$ perhaps the absence of analysis stems from a subtler judgment that Congress and union governing bodies have made findings they must respect. This possibility necessitates a closer examination of the contract and statutory theories.

At the outset, it should be noted that the title I exhaustion proviso states only that a "member may be required to exhaust reasonable hearing procedures" within his union..$^{90}$ Similarly, only members of unions can be said to be contractually obligated to comply with exhaustion requirements in their union constitutions. Where does this leave the non-member employee? Does the intraunion exhaustion doctrine not apply to section 301 actions brought by non-members? Clearly, when processing grievances, unions owe a duty of fair representation to all employees in their bargaining units, members and non-members alike. Inevitably, non-members as well as members will initiate section 301 actions alleging a breach of this duty. By refusing to join, or by resigning from the union, can workers eliminate this significant hurdle to prosecution of their breach of contract suits against their employers?

Very possibly, yes. Indeed, in Soto Segarra v. Sea-Land Service, Inc. ${ }^{91}$ the first case in which the issue has arisen, the First Circuit squarely held that "[s]ince appellee was not a union member, he was not bound by contract with the union to exhaust any formal internal union appeals before resorting to a judicial forum." 92 Similarly, because the title I exhaustion proviso also applies only to union members, it cannot supply a legitimate foundation for the exhaustion doctrine in section 301 suits.

Few courts have recognized this disparity in treatment of members and non-members, much less attempted to reconcile it with their imposition of intra-union exhaustion as one of the prerequisites to section 301 litigation. This disparity in treatment, however, substantially erodes the theoretical and legal foundation

89 See note 67 supra.

90 LMRDA $\$ 101(\mathrm{a})(4), 29$ U.S.C. $\$ 411(\mathrm{a})(4)$ (1976) (emphasis added). 91581 F.2d 291 (1st Cir. 1978).

92 Id. 295. Cf. Buchholtz v. Swift \& Co., 102 L.R.R.M. 2219, 2220-21 \& n.3 (8th Cir. 1979), cert. denied, 48 U.S.L.W. 3436 (U.S. Jan. 8, 1980) (no comment on district court's reliance on member/non-member distinction); Neal v. System Bd. of Adjustment, 348 F.2d 722, 726 (8th Cir. 1965) (distinguishing cases involving non-members and stating non-members "had no internal union procedures available to them") (under the Railway Labor Act). 
for application of the intra-union exhaustion doctrine to section 301 litigation. To the extent that only union members may be saddled with the intra-union exhaustion requirement in addition to the grievance exhaustion requirement, the courts may be creating an incentive for workers to refuse to join, or to resign from, unions in order to have access to the courts when necessary to obtain workplace justice. Although some might acclaim this result, it may hardly be said to have been intended, and it certainly does not promote union interests.

Any contractual justification for the intra-union exhaustion requirement can certainly be criticized, therefore, because of its disparate impact on union members and non-members. The contract theory is, however, more fundamentally flawed. Indeed, respected scholars have challenged the argument that even members are contractually bound to exhaust intra-union remedies. ${ }^{93}$ Many employees are only "nominal" members, having joined the union because membership was a condition of employment under a unionsecurity clause in their contract. Even those employees who voluntarily seek full-fledged membership status are presented with a fully elaborated union constitution. The provisions of the constitution are not negotiated by the "parties"; in this sense, the union constitution is simply a contract of adhesion. The unfairness is greatest in the many instances in which courts have been willing to impose upon union members constructive knowledge of the union's constitutional appeals procedures.9t Unions are not required to supply members, whether "nominal" or full-fledged, with copies of their

${ }^{93}$ Although noting some departures from such uncritical application, Professor Clyde Summers has observed:

The most deeply embedded doctrine in the law of internal union affairs is that the union constitution is a contract which defines the rights and duties between a member and his union. The courts, seduced by its deceptive simplicity, have ignored its logical difficulties and have verbalized their decisions in rigid Willistonian terms. Their only function, they constantly reiterate, is to read the constitution and apply it.

Summers, Union Democracy and Union Discipline, NEW YORK UNTVERSTTY FIFTH ANNUAL CONFERENCE ON LABOR 443, 461 (1952).

In most states in which union-security clauses in labor agreements are not prohibited by "right-to-work" statutes, it may be necessary for employees to join the union, or at least to pay dues as nominal members, in order to retain their employment. The question has been raised whether, under these circumstances, the employee has voluntarily agreed to be bound by the union constitution which may be more accurately described as a contract of adhesion. Simpson \& Berwick, supra note 10, at 1221 . Indeed, union-security provisions can only require employees to become "nominal" members through the payment of dues, not to become "full-fledged" members by taking an oath subscribing to the union constitution. Local 680, Serv. Employees Int'l Union v. NLRB, 601 F.2d 980 (9th Cir. 1979). See also Nelson v. Johnson, 212 F. Supp. 233, 272 n.44 (D. Minn. 1963), affd, 325 F.2d 646 (8th Cir. 1963).

94 See cases cited in note 80 supra. 
constitutions, the source of information about both the exhaustion requirement and the appeals procedures. ${ }^{95}$ These difficulties seriously undermine any reliance on a contract theory to support the intra-union exhaustion doctrine.

A careful reevaluation of the applicability of the title I exhaustion proviso to section $30 \mathrm{l}$ suits is also necessary. Commentators have universally agreed that section 101(a)(4) of the LMRDA, containing the proviso, is "perhaps the most ambiguous of all [provisions] in the Act" and one which the legislative history does little to illuminate. ${ }^{96}$ What is clear is that the subsection was not intended to restrict, but rather to assure, the member's right to sue his union. ${ }^{97}$ As a basis for the section 301 exhaustion doctrine, however, the proviso seems to have been used to accomplish the opposite result.

The actual language of section $101(a)(4)^{98}$ is very broad; it would seem to apply to any action, including a section 301 suit, regardless whether the action seeks to enforce the member's civil or political rights afforded by the title I "Bill of Rights of Union Members." 99 If the exhaustion proviso had been intended by Congress to be applied whenever a member might sue his union,

95 LMRDA $\$ 201$ (a), 29 U.S.C. $\$ 431$ (a) (1976), requires unions only to adopt constitutions and bylaws and to file copies with the Department of Labor. There is no obligation to supply members with copies of these goverming instruments. Indeed, it can sometimes be difficult for members to obtain copies. See Farmer v. Hotel Workers Local 1064, 99 L.R.R.M. 2166, 2185 (E.D. Mich. 1978). Compare LMRDA $\$ 104,29$ U.S.C. $\$ 414$ (1976), requiring unions to provide employees with copies of their collective bargaining agreements.

96 Thatcher, Rights of Individual Union Members Under Title I \& Section 610 of the Landrum-Griffith Act, 52 GEo. L.J. 339, 350 (1964); see O'Donoghue, Protection of a Union Member's Right to Sue Under the Landrum-Griffith Act, 14 Catr. U. L. Rev. 215, 223-34 (1965); see also NLRB v. Industrial Union of Marine \& Shipbuilding Workers, 391 U.S. 418, 427 (1968).

97 The basic intent and purpose of the provision was to insure the right of a union member to resort to the courts, administrative agencies, and legislatures without interference or frustration of that right by a labor organization. On the other hand, it was not, and is not, the purpose of the law ... to invalidate the considerable body of State and Federal court decisions of many years [sic] standing which require, or do not require, the exhaustion of internal remedies prior to court intervention depending upon the reasonableness of such requirements in terms of the facts and circumstances of a particular case. So long as the union member is not prevented by his union from resorting to the courts, the intent and purpose of the "right to sue" provision is fulfilled ....

105 Cong. REc. 17899 (1959) (remarks of Sen. Kennedy). See Detroy v. American Guild of Variety Artists, 286 F.2d 75, 78 n.2 (2d Cir. 1961), cert. denied, 366 U.S. 929 (1961).

98 See note 81 supra.

99 See Operating Eng'rs Local 3 v. Burroughs, 417 F.2d 370, 373 (9th Cir. 1969), cert. denied, 397 U.S. 916 (1970); Cox, Internal Affairs of Labor Unions Under the Labor Reform Act of 1959, 58 MxcH. L. Rev. 819, 839-41 (1960) (acknowledging ambiguity but advocating broad view of $\$ 101(\mathrm{a})(4)$ ). 
then intra-union exhaustion would be appropriate not only in section 301 suits alleging a breach of the statutory duty of fair representation, but also in suits under title VII of the Civil Rights Act of $1964^{100}$ alleging racial discrimination by unions and in actions under the National Labor Relations Act charging unions with unfair labor practices. ${ }^{101}$ In Alexander v. Gardner-Denver Co., ${ }^{\mathbf{1 0 2}}$ however, the Supreme Court left little doubt that section 101(a)(4) may not be invoked to require intra-union exhaustion before initiating title VII suits; ${ }^{103}$ in NLRB v. Industrial Union of Marine of Shipbuilding Workers, ${ }^{104}$ the Court noted that the title I exhaustion proviso may not be employed to impede member access to public tribunals unless the union's "internal affairs" are involved. ${ }^{105}$ In that case, a worker had been expelled from his union for failing to exhaust internal union appeals before filing charges with the NLRB alleging that his union had unlawfully caused his employer to discriminate against him. ${ }^{106}$ Although no charges were filed against the employer, the Court stated:

The employer might also have been made a party and comprehensive and coordinated remedies provided [by the NLRB]. Those issues cannot be fully explored in an internal union proceeding. There cannot be any justification to make the public processes wait until the union member exhausts internal procedures plainly inadequate to deal with all phases of the complex problem concerning employer, union, and employee member. If the member becomes exhausted, instead of the remedies, the issues of

10042 U.S.C. $\$ \$ 2000 \mathrm{e}$ to $2000 \mathrm{e}-17$ (1976).

101 NLRA $\$ 8(b), 29$ U.S.C. $\$ 158(b)$ (1976).

102415 U.S. $36,56-60$ \& n.19 (1974).

103 In two cases predating Gardner-Denver, courts of appeals had found exhaustion requirements justified in suits challenging discriminatory labor practices. Both cases arose under the Railway Labor Act. Foy v. Norfolk \& W. Ry., 377 F.2d 243 (4th Cir.), cert. denied, 389 U.S. 848 (1967); Neal v. System Bd. of Adjustment, 348 F.2d 722 (8th Cir. 1965). Presumably, these cases are no longer good law.

104391 U.S. 418 (1968).

105 Id. 426 n.8.

106 To be sure, Marine Workers involved an NLRB proceeding, rather than a section 301 claim of violation of the union's duty of fair representation. It is also true that the issue before the Court was narrow: whether the section 101(a)(4) exhaustion proviso in the LMRDA authorizes unions to discipline a member for failure to exhaust union remedies before filing a complaint with the NLRB. The Court's analysis of that situation is, however, quite relevant in the section 301 setting. See text following note 107 infra for a discussion of the Court's analysis and its relevance to $\$ 301$ litigation. But see Battle v. Clark Equip. Co., 579 F.2d 1338, I344 (7th Cir. 1978) ("the public policy aspects of labor disputes are of greater importance in unfair labor practice suits before the NLRB than in Section 301 (a) suits, which focus more on the vindication of private contract rights"). 
public policy are never reached and an airing of the grievance never had. ${ }^{107}$

No less than the employee's charges in Marine Workers, a typical section 301 action involves "a complex problem concerning the employer, union and employee." That the employee bringing a section 301 suit need not be a union member ${ }^{108}$ serves only to move the situation even farther from the "internal affairs" setting. This background suggests that the section 101 (a)(4) exhaustion proviso is also inapplicable in section 301 litigation.

Although the intra-union exhaustion doctrine in the section 301 setting has, since the decision in Marine Workers, achieved a level of acceptance approaching judicial dogma, few courts have attempted to reconcile the doctrine with the Supreme Court's teachings in Marine Workers. ${ }^{109}$ In Chambers v. Local 639, International

107391 U.S. at 425 .

108 This distinction between the member-union and employee-employer relationship was actually drawn by the Third Circuit in Brady v. Trans World Airlines, Inc., 401 F.2d 87 (3d Cir. 1968), cert. denied, 393 U.S. 1048 (1969), a decision subsequently cited as authority for the extension of the intra-union exhaustion doctrine to section 301 litigation. In Brady, the court held that exhaustion of union remedies is appropriate only when the employee's claim concerns the internal, member-union relationship. Id. 104. Brady's discharge by TWA had been precipitated by the union when he refused to pay a dues increase he had disputed. Hence, although Brady alleged that the union violated its duty of fair representation, his claim against the union actually arose from the internal, member-union relationship and implicated title I rights and the IMRDA exhaustion provision. Indeed, the court itself recognized the confusion of the unfair-representation and title I claims, noting that "[ $t]$ he complaint and its amendments [were] artlessly drawn and the prayers for relief [were], to say the least, confusing." Id. 103. Brady is not authority for the proposition that valid unfair-representation claims automatically involve internal union concerns.

Reliance on Brady as support for the intra-union exhaustion doctrine is also troublesome because, contrary to the teachings of Vaca v. Sipes, 386 U.S. 171 (1967), the court treated Brady's contract and unfair-representation claims as separate and independent causes of action. Thus, although it dismissed Brady's unfair-representation action against the union for failure to exhaust, it proceeded to find that the union had improperly asked TWA to discharge him and that the discharge was in violation of contract; the court then awarded against TWA the relief requested. Most $\$ 301$ courts have, in contrast, followed Vaca and held that the employee's contract claim cannot be considered until a breach of fair representation by the union has been found. These courts have then relied on the intra-union exhaustion doctrine to dismiss the employee's suit against the employer as well as against the union, a decidedly harsher result than that in Brady. E.g., Neipert v. Arthur G. McKee \& Co., 448 F. Supp. 206 (E.D. Pa. 1978); Pawlak v. Teamsters Local 764, 444 F. Supp. 807, 811-12 (M.D. Pa. 1977), affd, 571 F.2d 572 (3d Cir. 1978); McFadden v. Ford Motor Co., 89 L.R.R.M. 2398, 2400 (E.D. Mich. 1975); Ward v. Local 45, UAW, 87 L.R.R.M. 2813, 2815 (N.D. Ohio 1972). But see note 85 supra.

109 But see Derr v. Bright, 297 F. Supp. 12, 15-16 (M.D. Pa. 1969); Harrison v. Arrow Metal Prods. Corp., 20 Mich. App. 590, 623-24, 174 N.W.2d 875, 891-92 (1969) (concurring and dissenting opinion). After these two opinions in 1969, Marine Workers lay dormant until 1978 when it was resurrected by the District of Columbia Circuit in Chambers v. Local 639, Int'l Bhd. of Teamsters, 578 F.2d 375 (D.C. Cir. 1978). 
Brotherhood of Teamsters, ${ }^{110}$ however, the District of Columbia Circuit recently recognized the significance of Marine Workers and relied upon it to find improper the requirement that intra-union procedures be exhausted before initiating a section 301 action which it characterized as focusing "on the employment relation rather than the union relation, though the alleged improper activity by the union may be an integral part and contributing cause of the damages suffered by [plaintiffs]." 111 Examining the plaintiffs' requested relief, the court found that it would be "repugnant to fundamental requirements of fairness" to require exhaustion of internal union procedures which were plainly inadequate to remedy employer violations. ${ }^{112}$

Although union conduct is an issue in most section 301 actions, the focus typically has not been upon purely internal union political or constitutional matters, but rather upon the union's breach of its duty of fair representation, an issue which raises no less a statutory question than whether title VII of the Civil Rights Act of 1964 or the LMRDA has been violated. Alleged union violations of statutory duties automatically raise questions involving public, rather than internal union policies. The duty of fair representation is, after all, a statutory obligation owed by the union to all employees regardless of their union status.

The cases construing section 101(a)(4), particularly Marine Workers and Chambers, assuredly suggest that before the exhaustion proviso of title I may properly be invoked by the courts, at least in the section 301 context, the "internal affairs" test must be met. Although some may still wonder if such a test is valid in light of the exceedingly broad language of the proviso, a brief review of the LMRDA should allay any such concerns. Recall that the LMRDA was intended to make unions democratic institutions. ${ }^{113}$ Title I, also known as the union members' "Bill of Rights," guarantees the political or civil rights of union members to speak and assemble freely; ${ }^{114}$ to attend union meetings and to participate and vote in

110578 F.2d 375 (D.C. Cir. 1978).

111 Id. 386-87 (emphasis in original).

112 Id. 387-88. See Brady v. Trans World Airlines, Inc., 401 F.2d 87 (3d Cir. 1968), cert. denied, 393 U.S. 1048 (1969); Derr v. Bright, 297 F. Supp. 12 (M.D. Pa. 1969). But see NLRB v. International Bhd. of Boilermakers, 581 F.2d 473, 476 ( 5 th Cir. 1978) (discipline of union steward for filing NLRB charges against company "is no less 'internal' because the policy sought to be enforced is embodied in collective bargaining agreement rather than in a union's constitution or by-laws").

113 See, e.g., United Bhd. of Carpenters v. Brown, 343 F.2d 872, 883 (10th Cir. 1965).

114 LMRDA \$101(a)(2), 29 U.S.C. \$411(a)(2) (1976). 
elections and deliberations on union business, ${ }^{115}$ including the approval of dues and assessments; ${ }^{110}$ to receive certain due-process protections during union disciplinary hearings; ${ }^{117}$ and, of course, to institute legal actions against their unions subject to the exhaustion proviso.118 Title I claims inevitably involve the member-union relationship-plainly an internal matter.

The LMRDA's other titles have either separate exhaustion provisions or none at all, perhaps suggesting that the title I exhaustion proviso was intended to apply only to suits by members against their unions to secure their title I membership rights. ${ }^{119}$ For example, title II authorizes members to sue to require that their unions make available for inspection their financial records, ${ }^{120}$ with the only apparent condition being demonstration of "just cause." 121 In title III suits to lift trusteeships, ${ }^{122}$ the courts have specifically found the section $101(a)(4)$ exhaustion proviso inapplicable..$^{123}$ Under title IV, members are denied the right to sue their unions directly to set aside undemocratic elections; rather, they may only request the Secretary of Labor to sue on their behalf after they have exhausted intra-union remedies for a maximum of three months. ${ }^{124}$ The titles I and IV exhaustion requirements not only involve time limits which differ in length by a month, but exhaustion is mandatory under title IV yet permissive under title I. ${ }^{\mathbf{1 2 5}}$ Finally, title V authorizes members to sue their union officers for breach of fiduciary duty if, after having been afforded a reasonable opportunity to act on a request by the member, the union fails to initiate proceedings

115 LMRDA $\$ 101(a)(1), 29$ U.S.C. $\$ 411(a)(1)$ (1976).

116 LMRDA $\$ 101(\mathrm{a})(3), 29$ U.S.C. $\$ 411$ (a)(3) (1976).

117 LMRDA $\$ 101(\mathrm{a})(5), 29$ U.S.C. $\$ 411(\mathrm{a})(5)$ (1976).

118 LMRDA $\$ 101(\mathrm{a})(4), 29$ U.S.C. $\$ 411(\mathrm{a})(4)$ (1976). I965).

119 See United Bhd. of Carpenters v. Brown, 343 F.2d 872, 881 (10th Cir.

120 LMRDA $\$ 201(\mathrm{c}), 29$ U.S.C. $\$ 431$ (c) (1976).

121 See Fruit \& Vegetable Packers Local 760 v. Morley, 378 F.2d 738, 744 (9th Cir. 1967) (just-cause standard "minimal," requiring only that member have reasonable basis for requesting inspection).

122 LMRDA $\$ 304,29$ U.S.C. $\$ 464$ (1976).

123 See, e.g., United Bhd. of Carpenters v. Brown, 343 F.2d 872, 881 (10th Cir. 1965) ("[s]ection 101(a)(4) is applicable only where individual violations of the so-called Bill of Rights provisions are alleged and does not apply where, as here, the validity of a trusteeship is being challenged"). But cf. Local 13410, UMW v. UMW, 475 F.2d 906, 910 n.6 (D.C. Cir. 1973) (failure to exhaust does not preclude judicial intervention when exhaustion "futile").

124 LMRDA $\$ 402,29$ U.S.C. $\$ 482$ (1976).

125 Compare $\$ 402$ with $\$ 101(a)(4)$, as construed by the Supreme Court in Marine Workers, 391 U.S. at 426 (under $\$ 101(a)(4)$, "public tribunals whose aid is invoked may in their discretion stay their hands for four months, while the aggrieved person seeks relief within the union"). 
or to take other appropriate action. ${ }^{126}$ A sweeping, all-inclusive reading of the title $I$ exhaustion proviso is difficult to reconcile with these other, clearly distinct provisions in the LMRDA.

A comprehensive reading of the LMRDA thus discloses that Congress explicitly created a number of separate and distinct prerequisites to suit in each of the several titles. If the title I exhaustion proviso cannot be said to apply even to other LMRDA suits by members against their unions when those suits do not directly involve their title I political or civil membership-rights, it becomes difficult to argue that the proviso was intended nonetheless to extend to virtually all legal proceedings initiated by members, including section 301 suits. Yet, this is in fact what courts in section 301 cases have assumed.

To the extent that the duty of fair representation has a parallel in the LMRDA, it more closely resembles the fiduciary duty owed by union officers to their members under title $V^{127}$ than any duty created by title $I^{128}$ Yet, as we have seen, a member is required by section 501 only to have requested without success that his union seek appropriate relief, before bringing his own suit against the officer for breach of a title $V$ fiduciary duty. In short, the member need not exhaust any particular intra-union procedures before suing under section 501. Moreover, there is some reason to believe that the union may not only wish, but may also be able, to pursue an officer's breach of his section 501 fiduciary duty to the membership and to recover misappropriated funds from the officer and other relief necessary to protect itself as an institution. In contrast, the union has no comparable incentive to remedy a breach of its duty of fair representation by providing injured members with a monetary award from its own treasury. ${ }^{129}$ Hence, even the section 501 exhaustion requirement is an inappropriate prerequisite to bringing a section 301 suit.

126 LMRDA $\$ 501(b), 29$ U.S.C. $\$ 501$ (b) (1976). See Purcell v. Keane, 406 F.2d 1195 (3d Cir. 1969) (holding, after careful analysis, that "[i]t is quite evident that the intent of Congress was to adopt a separate procedure under 501 (b) free from the exhaustion restriction set forth in $\left.411(\mathrm{a})(4)^{\prime \prime}\right)$. But cf. Coleman v. Brotherhood of Ry. \& Steamship Clerks, 228 F. Supp. 276, 284 (S.D.N.Y. 1964), affd, 340 F.2d 206 ( $2 \mathrm{~d}$ Cir. 1965) (when not futile, failure to exhaust grounds for dismissal).

127 LMRDA \$501, 29 U.S.C. \$501 (1976).

128 See Clark, The Fiduciary Duties of Union Officials Under Section 501 of the LMRDA, 52 MINN. L. REv. 437, 478-81 (1967); see also Brady v. Trans World Airlines, Inc., 401 F.2d 87, 94 (3d Cir. 1968), cert. denied, 393 U.S. 1048 (1969). 129 See text accompanying notes 61-68 supra. Moreover, it would be futile to ask a union to overturn a grievance settlement or arbitral award defined by the contract to be final and binding on the parties. See, e.g., Miller v. Gateway Transp. Co., 103 L.R.R.M. 2591, 2593 n.5 (7th Cir. 1980). This obstacle does not arise in the section 501 context. 
In light of this comparison of the duty-of-fair-representation requirements with those under the somewhat similar fiduciary duty of title $\mathrm{V}$, the contrast with title I now seems even sharper. Application of the title $I$ exhaustion proviso in cases involving title $I$ membership rights is of course entirely appropriate; not only does it avoid undue judicial interference with a union's purely internal, political affairs, it also encourages the development of responsible, democratic governing processes. Extension of the exhaustion requirement to section 301 actions, on the other hand, not only does not promote responsible union conduct, it may well inspire disingenuous union action aimed at depriving employees of their statutory right to fair representation. ${ }^{130}$ From a policy, as well as a legal, point of view, extension of the title I exhaustion proviso to section 301 actions is indefensible.

Thus, the "internal affairs" test suggested by the Marine Workers opinion seems a valid way of narrowing the applicability of the loosely worded title I exhaustion proviso. The duty-of-fairrepresentation issue raised in section 301 litigation extends beyond a union's purely internal affairs into the public arena. Indeed, the duty of fair representation is owed to all employees represented by unions, members and non-members alike, while the language of the title I proviso purports to require only "members" to exhaust internal union procedures before suing their unions. Similarly, only full-fledged members who have voluntarily joined their unions may even arguably be said to be bound contractually to honor constitutional exhaustion requirements. Neither the statutory nor the contract theories invoked by the courts in fact support their extension of the intra-union exhaustion doctrine to section 301 actions initiated by employees. Thus, we discover that, in addition to failing to promote the interest of employees seeking vindication of their collective bargaining rights or the interests of courts in simplifying issues or avoiding litigation entirely, the intra-union exhaustion doctrine as currently applied by most courts serves no legitimate employer or union interests.

130 See text accompanying notes 57 \& 61-68 supra. Additional problems, beyond the distortions of facts and issues in written opinions designed to avoid liability, may arise when the intra-union procedures include consideration of the claim by the membership and/or convention delegates. Unpopular employees, dissidents, and minority groups may soon discover that their very clear contract rights are being sacrificed in the name of majority rule. When statutory issues are involved, requiring exhaustion of democratic procedures within private institutions invites discrimination in violation of laws and public policies. See Sciaraffa v. Oxford Paper Co., 310 F. Supp. 891 (D. Me. 1970) (doubt about fairness of vote by "predominantly male union membership" on discrimination claim by women employees); General Truck Drivers, 217 N.L.R.B. 616 (1975), aff'd, 545 F.2d 1173 (9th Cir. 1976). 


\section{The Rare Case in Which Application of the Intra-Union} Exhaustion Doctrine May Be Justified

\section{A. The Proper Perspective}

A strong argument can be made that intra-union exhaustion has no place in any unfair-representation case, whether or not associated with a section 301 contract claim. To be sure, the typical unfair-representation claim is filed by a member against his union, but fair representation is not a right of union membership. Rather, it is a statutory duty owed by the union to all employees in the bargaining unit by virtue of their employment relationship. Employees in the bargaining unit who are not at the same time union members can still sue for injuries resulting from unfair union representation. ${ }^{131}$ If union membership is thus irrelevant, why should it enter the calculus when the aggrieved employee is by chance a union member? After all, the employee is still seeking only to vindicate rights conferred by federal statute. When courts in section 301 cases speak of "forestall[ing] judicial interference with the internal affairs of a labor organization" to allow it to "resolve disputes concerning its own legitimate affairs," 132 they misconstrue the basic character of the duty-of-fair-representation complaint. ${ }^{133}$ Fair representation in any form is simply not an internal union membership dispute arising under the union constitution. ${ }^{134}$

When a claim of unfair representation is joined with a breachof-contract claim against the employer-as is typical in section 301 litigation-the argument for abolishing the exhaustion doctrine altogether is strengthened considerably. As we have seen, the two claims, though distinct in theory, are inextricably linked in prac-

131 Steele v. Louisville \& N. R.R., 323 U.S. 192 (1944) (under Railway Labor Act).

132 Brady v. Trans World Airlines, Inc., 401 F.2d 87, 104 (3d Cir. 1968), cert. denied, 393 U.S. 1048 (1969) (emphasis added) (under Railway Labor Act). 133 Professor David Feller has labelled the intra-union exhaustion requirement in section 301 cases "plainly erroneous." He has observed:

It imposes a bar based on a right arising out of union membership to a suit in which membership is irrelevant and which is based solely on employee status and section 9 [of the NLRA]. If the employee has filed a grievance.... and the union official charged with the responsibility of processing his claim refuses to proceed, the employee should not be required to appeal through the union hierarchy before filing suit.

Feller, supra note 1, at 813-14 (footnotes omitted).

134 The distinction can be further illustrated by analogizing to another situation in which a member's statutory rights would clearly conflict with his obligations to exhaust remedies under his union constitution. Suppose a member rents an apartment in a union-owned building and discovers that it is infested with rats and contains fire hazards. Should the member be required to exhaust all internal union appeals before reporting the violations of health and fire codes? 
tice. ${ }^{135}$ Much that is involved in the claim of unfair representation turns on the outcome of the underlying contract claim, while the contract claim requires an initial proof of unfair representation. Indeed, in Vaca v. Sipes the Supreme Court acknowledged "the intricate relationship between the duty of fair representation and the enforcement of collective bargaining contracts." 136 To call fair representation in the section 301 context an internal union dispute is therefore doubly wrong: neither the fair-representation nor the contract issue involves "internal" union-member concerns. Two inseparable claims are involved, and even if the union were competent to handle one-which it is not-it would be simpler and more desirable to deal with both claims simultaneously in a single proceeding.

As we have seen, the District of Columbia Circuit recently relied upon the "internal affairs" test of $N L R B$ v. Industrial Union of Marine of Shipbuilding Workers ${ }^{137}$ in finding that it would be improper to require exhaustion of intra-union procedures before initiating a section 301 action-an action which "focuses on the employment relation rather than the union relation, though the alleged improper activity by the union may be an integral part and contributing cause of the damages suffered by [plaintiffs]." ${ }^{138}$ The court's carefully reasoned decision may well signal that the judiciary is ready to look more skeptically at the use of intra-union exhaustion in section 301 actions. Particularly because the doctrine has grown largely by accretion, with almost no serious consideration having been given to its actual effects, such skepticism is long overdue.

\section{B. Reactivation of Grievance Procedures}

To this point our argument has proceeded on a critical, albeit entirely reasonable, assumption-that the contract statute of limitations has run and intra-union appeals can no longer reactivate the employee's contract grievance. ${ }^{139}$ However, in the highly unusual situation in which the grievance can be reactivated and the grievant assured of fair representation in the resumed proceeding, so that the grievance may yet be resolved pursuant to the contract grievance machinery, our conclusion that intra-union appeals can provide no

135 See text accompanying notes 22-27 supra.

136386 U.S. 171, 183 (1967).

137391 U.S. 418,426 n.8 (1968).

138 Chambers v. Local 639, Int'l Bhd. of Teamsters, 578 F.2d 375, 387 (D.C.

Cir. 1978) (emphasis in original). See text accompanying notes 110-112 supra. 139 See text accompanying notes $48-49$ supra. 
meaningful relief must be qualified. ${ }^{140}$ The critical difference is a matter of available remedies. Although union tribunals certainly cannot require employers to reinstate terminated employees, pay back wages, restore seniority, and the like, arbitrators can. Under these circumstances, the imposition of an intra-union exhaustion requirement may be appropriate, though other circumstances may counsel against even this limited application..$^{141}$

Moreover, when an intra-union appeal can precipitate arbitration of the employee's contract claim, it serves not only the employee's interest in obtaining resolution of his claim, but also the federal policy encouraging the settlement of labor disputes by arbitrators-that is, by those presumed to be expert in the law of the shop. ${ }^{142}$ Under these narrow circumstances, there may be sound reasons of policy to justify the application of an intra-union exhaustion doctrine-though not for the reasons customarily offered by the courts. ${ }^{143}$

As reformulated, the intra-union exhaustion doctrine would be confined to just those cases in which (1) union tribunals are constitutionally authorized to reactivate grievances, (2) the union can be expected to provide full and fair representation once the grievance is reinstated, and (3) the collective bargaining agreement explicitly allows grievances to be reactivated by union tribunals. ${ }^{144}$ Were the doctrine so confined, the parties to collective bargaining would have an incentive to develop meaningful procedures qualifying for temporary judicial deference. To the extent that such new procedures actually enable aggrieved employees to obtain prompt and fair grievance hearings and ultimate disposition of their contract claims, federal policy and the interests of all the parties would be served; indeed, it is possible that much section 301 litigation could be avoided. The mere possibility of reactivation is not enough; the

140 The relief afforded by the union tribunal does not, of course, remedy the alleged contract violation. That relief generally can be secured only pursuant to contract grievance-arbitration procedures. infra.

141 For discussion of these difficulties, see text accompanying notes 147-171

142 See Soto Segarra v. Sea-Land Serv., Inc., 581 F.2d 291, 296 (1st Cir. 1978); Orphan v. Furnco Constr. Corp., 466 F.2d 795, 801 (7th Cir. 1972); Miller v. Local 50, Am. Fed'n of Grain Millers, 468 F. Supp. 193, 198 (D. Neb. 1979). 143 See text accompanying notes 9-17 supra.

144 Of course, whenever a union has already entered into a "final settlement" of the grievance, the union is contractually prohibited from repudiating that settlement by seeking to reactivate the underlying grievance. See, e.g., Miller v. Gateway Transp. Co., 103 L.R.R.M. 2591, 2593 n.5 (7th Cir. 1980); Buchholtz v. Swift \& Co., 102 L.R.R.M. 2219, 2221 (8th Cir. 1979), cert. denied, 48 U.S.L.W. 3436 (U.S. Jan. 8, 1980). Decisions by all Teamster bipartite labor-management grievance committees, for example, are contractually defined as final and binding awards. But see Fizer v. Safeway Stores, Inc., 586 F.2d 182 (10th Cir. 1978). 
procedures should yield positive results. If they fail to reactivate grievances and to restore fair representation after a reasonable trial period, the courts should treat them no differently from conventional intra-union appeals. ${ }^{145}$

\section{Procedural Guidelines for Application of the Intra-Union Exhaustion Doctrine}

Even when, because of unusual circumstances, an intra-unionexhaustion requirement may be appropriate, the courts should impose procedural safeguards to ensure that employees' rights are not prejudiced. First, the courts must develop a clear definition of what constitutes exhaustion. Second, the burden of demonstrating that the exhaustion doctrine is appropriate under the circumstances should be imposed upon the party urging exhaustion. Finally, unions should be required to provide such information and other assistance as are necessary to enable members effectively to pursue intra-union appeals.

\section{The Need for a Glear Definition of Intra-Union Exhaustion}

A clear picture of what an employee must do to exhaust intraunion remedies has yet to emerge from section 301 cases. Some courts have said that a member need give his union only a "reason-

145 There may, however, be a situation in which intra-union exhaustion of remedies is still appropriate. When the collective bargaining agreement actually designates the intra-union appellate process as the mechanism for resolving contract disputes, or when it has functioned in that manner in practice, exhaustion of the union remedies may be the equivalent of exhaustion of contract remedies as mandated by Republic Steel Corp. v. Maddox, 379 U.S. 650 (1965).

An example of this exceptional case is presented in Battle v. Clark Equip. Co., 579 F.2d 1338 (7th Cir. 1978). At issue in that case was the formula by which employees would be entitled to "Supplemental Unemployment Benefits" (SUB), which the employer was contractually obliged to pay following a plant shutdown. The employer acquiesced to a union request that the formula for distribution of SUB funds be modified from an equal amount per employee to a graduated formula based upon seniority. The employer's liability was not affected by the change, so it stood in the position of a disinterested stakeholder. The contract explicitly required an internal union appeal to resolve disputes concerning the interpretation or application of the SUB plan. Intra-union exhaustion was appropriate because the disputes arose under a contract provision in an agreement in which the union was delegated responsibility for construing the provision and had the ability to remedy the problem. A similar situation might arise were a union to refuse to refer members to jobs under an "exclusive hiring hall" arrangement which it independently administered. See Davis v. Local 242, Laborers, 84 L.R.R.M. 2544 (W.D. Wash. 1973).

Such agreements are relatively rare today and are found only in a few trades (music, printing, construction) in which employers merely subscribe to "agreements" written by a union that represents employees who are usually needed on only a temporary basis. See generally Feller, supra note 1, at 724-36. Of course, exhaustion of union remedies under such "trade agreements" cannot be lumped with exhaustion of such remedies under conventional agreements. 
able opportunity" to take action on his complaint. ${ }^{146}$ Others have required, regardless of the time involved and the possibility that the statute of limitations for filing suit may run out during the process, that the employee exhaust every appeal provided by the union constitution up to, and including, appeal to international conventions. ${ }^{147}$ As a result, employees have little idea how far, or how long, they must pursue union appeals. Unions, on the other hand, have an incentive to multiply the number of appeals that a member must pursue and to procrastinate in processing those appeals in the hope of exhausting the member and frustrating his pursuit of legal remedies in the courts.

This unsatisfactory situation demands judicial clarification. The better approach would be to structure exhaustion requirements in terms of elapsed time rather than in terms of available procedures which vary widely from union to union, imposing small burdens on some section 301 plaintiffs and great burdens on others. Moreover, a requirement of limited duration would prevent the troublesome proliferation of appeals and force unions to deal with duty-offair-representation complaints expeditiously or not at all. A four-month limit, as in the LMRDA exhaustion proviso, ${ }^{148}$ seems appropriate when exhaustion is required under section 301 . Under the proviso, union members are presumed to have exhausted their union appeals four months after seeking relief from their unions. Congress's conclusion that four months offers sufficient opportunity for unions to remedy violations of their members' title I civil rights provides some evidence that unions cannot reasonably require a longer period to remedy violations of their members' right to fair representation. To require more risks exhausting the member rather than the remedies. Moreover, by adopting the title I time limit, the intra-union exhaustion doctrine would at least be made more uniform.

\section{Demonstration of Propriety of Application of Doctrine}

Because exhaustion of intra-union remedies rarely serves any useful purpose in section 301 litigation, the courts should presume that exhaustion of such remedies is futile. ${ }^{149}$ A party wishing to

146 E.g., Goclowski v. Penn Central Transp., 571 F.2d 747 (3d Cir. 1977).

147 E.g., Foley v. Chrysler Corp., 78 L.R.R.M. 2744 (S.D. Ind. 1971). See text accompanying notes $34-47$ supra.

148 See note 81 supra.

149 "Cumbersome, ineffective, time-consuming and inherently biased union appeals procedures should be deemed futile as a matter of law." Tobias, Individual Employee Suits for Breach of the Labor Agreement and the Union's Duty of Fair Representation, 5 U. ToL. L. REv. 514, 532 (1974). See note 67 supra. 
attack the presumption should have the burden of pleading and proving (l) that the particular internal union appeals procedure has actually operated, or can reasonably be expected to operate, to resolve fair-representation issues quickly and fairly, to reactivate withdrawn or abandoned grievances, and to restore fair representation, and (2) that the contract permits the grievance to be reactivated by a union tribunal without prejudice to the grievant..$^{150}$

The burden of establishing that intra-union exhaustion is appropriate in a given situation may quite reasonably be placed upon the parties who not only profit from its application but also possess virtually all the relevant information. Only the union can supply concrete information about the purpose, structure, and actual operation of its appeals process. As a co-defendant, the employer should have little difficulty obtaining this information from the union. The individual employee, however, is generally unfamiliar with the intra-union appeals process ${ }^{151}$ and normally would have to rely on discovery to acquire such information. To impose upon the employee the burden of proving that intra-union appeals would be futile is to impose an unjust handicap which will, in most cases, prove fatal to his suit. ${ }^{152}$

The procedural rules currently governing intra-union exhaustion in section 301 litigation are chaotic. As a result, section 301 plaintiffs have little idea of what is necessary to preserve their cause of action, and are often caught totally off guard. Courts have held that intra-union exhaustion is a "prerequisite" to suit under section 301; what is meant by use of the term is not clear. Some of these courts have suggested that intra-union exhaustion is a "jurisdictional prerequisite" to a section 301 suit, with dismissal presumably appropriate under rule 12 (b) of the Federal Rules of Civil Procedure. ${ }^{153}$ Most courts have, however, qualified the term, finding

150 Employees should not be required to pursue intra-union remedies even for four months if the contract statute of limitations runs for a shorter period or has already expired.

151 See text accompanying notes 165-66 infra.

152 See notes 44-47 supra.

153 E.g., Csanadi v. Teamsters Local 773, 463 F. Supp. 276, 282 (E.D. Pa. 1978) ("Csanadi's failure to exhaust his internal union remedies or, in the alternative, his failure to present an adequate reason to avoid the exhaustion requirement, deprives this Court of jurisdiction to hear his complaint of unfair representation ... ."); Pullen v. General Motors Corp., 444 F. Supp. 87, 89 (E.D. Mo. 1978); Jenkins v. General Motors Corp., 364 F. Supp. 302, 309 n.10 (D. Del. 1973) (dismissal for failure to exhaust union remedies though such remedies time-barred when suit dismissed); Foley v. Chrysler Corp., 78 L.R.R.M. 2744 (S.D. Ind. 1971); Harrington v. Chrysler Corp., 303 F. Supp. 495, 497 (E.D. Mich. 1969). But see Dorn v. Meyers Parking Sys., 395 F. Supp. 779, 782 n.3 (E.D. Pa. 1975) (complaint failing to allege intra-union exhaustion not to be dismissed under FED. R. CIv. P. 12(b)(6)). 
exhaustion to be a prerequisite only when remedies are available within the union. ${ }^{154}$ The effect of this qualification is to shift the burden of pleading to the defendant, requiring him to allege as an affirmative defense the existence of some intra-union appellate process which the plaintiff has not pursued. Typically, this burden is met by a union's motion for summary judgment supported by an affidavit from a union official. The employee is then expected to make a "clear and positive showing of futility" 155 supported by solid evidence, not conclusory allegation, in his responsive pleading. Under rule 56 of the Federal Rules of Civil Procedure, this response may be due within ten days. ${ }^{156}$ The employee must generally respond without benefit of discovery. Under these circumstances, it is no wonder that many section 301 plaintiffs succumb to motions for summary judgment.

Finally, a few courts have placed upon the party urging exhaustion as a defense the burden not only of raising the plaintiff's failure to exhaust, but also of demonstrating that the internal union appeals procedure "so certainly holds out the prospect of . . . relief that the plaintiffs could justifiably be expected to have recourse to it before fling suit." 157 Because unions cannot remedy employer contract violations or reactivate dead grievances, and because only the union can enlighten the court regarding its own appeals procedures, this course is clearly the only acceptable one.

The positive effect of shifting the burden of proof from the employee-plaintiff to the union- or employer-defendant can be readily demonstrated. In Yeager $v$. C. Schmidt o Sons, Inc. ${ }^{158}$ for example, the court held that the Teamsters Union was obligated to show that its internal appeals procedures were "reasonably calcu-

154 E.g., Newgent v. Modine Mfg. Co., 495 F.2d 919, 927 (7th Cir. 1974); Neal v. System Bd. of Adjustment, 348 F.2d 722, 726 (8th Cir. 1965) (under Railway Labor Act); Gainey v. Brotherhood Ry. Steamship Clerks, 275 F.2d 342, 345 (3d Cir.), cert. denied, 363 U.S. 911 (1960) (under Railway Labor Act). 155 Imel v. Zohn Mfg. Co., 481 F.2d 181, 184 (10th Cir. 1973), cert. denied, 415 U.S. 915 (1974).

156 See, e.g., Willetts v. Ford Motor Co., 583 F.2d 852, 856 (6th Cir. 1978); Foy v. Norfolk \& W. Ry., 377 F.2d 243, 246-47 (4th Cir.), cert. denied, 389 U.S. 848 (1967) (under Railway Labor Act); White v. Remsco Management, Inc., 91 L.R.R.M. 2647, 2650 (E.D. Mo. 1976); Aldridge v. Ludwig-Honold Mfg. Co., 385 F. Supp. 695, 699 (E.D. Pa. 1974), affd, 517 F.2d 1397 (3d Cir.), cert. denied, 423 U.S. 937 (1975); Brookins v. Chrysler Corp., 381 F. Supp. 563, 566 (E.D. Mich. 1974).

157 Orphan v. Furnco Constr. Corp., 466 F.2d 795, 801 (7th Cir. 1972) (describing employer's burden of proof). See also Frederickson v. System Fed'n 114, 436 F.2d 764, 768-69 (9th Cir. 1970) (under Railway Labor Act); Patterson v. Bailystoker \& Bikur Cholim, Inc., 95 L.R.R.M. 3115, 3116 (S.D.N.Y. 1977); Dorn v. Meyers Parking Sys., 395 F. Supp. 779, 785-86 (E.D. Pa. 1975).

158343 F. Supp. 927 (E.D. Pa. 1972), and 355 F. Supp. 332 (E.D. Pa. 1973). 
lated to redress the particular grievance complained of." 159 Then, in an unusual step, the court ordered the union to provide specific facts in response to judicial interrogatories designed to test the union's assertion that the internal remedy was real and not illusory. After reviewing the union's response, the court held that the procedures set out in article XIX of the Teamster constitution "do not provide a reasonable method whereby [plaintiff] could seek relief from the union's failure to take his grievance to arbitration." 160

Curiously, although several courts have relied upon precedents holding that particular union appeals procedures can afford relief for individual employees and hence must be exhausted, ${ }^{161}$ no court has relied upon Yeager to deny a motion to dismiss in the many Teamster cases in which application of the intra-union exhaustion doctrine has been urged.182 Indeed, several courts have subsequently dismissed section 301 actions brought by Teamster members, merely citing article XIX of the union constitution and the plaintiffs' failure to prove futility. ${ }^{163}$ Given the scope of the court's discovery and the depth of its analysis of article XIX in Yeager, to require Teamster plaintiffs in each subsequent case to prove futility is to demand that they repeatedly "reinvent the wheel." Obviously, shifting the burden from the plaintiff-employee to the defendantunion can achieve very different results and avoid prejudice to the plaintiff's rights. ${ }^{164}$

159343 F. Supp. at 929 (emphasis in original).

160355 F. Supp. at 334 .

161 See, e.g., cases cited in note 52 supra.

162 The Teamsters Union has been involved in reported section 301 decisions in which application of the intra-union exhaustion doctrine has been considered more often than any union other than the UAW.

103 Fizer v. Safeway Stores, Inc., 586 F.2d 182 (10th Cir. 1978); Winter v. Local 639, Int'l Bhd. of Teamsters, 569 F.2d 146 (D.C. Cir. 1977); Csanadi v. Teamsters Local 773, 463 F. Supp. 276 (E.D. Pa. 1978); McGovern v. Teamsters Local 773, 447 F. Supp. 368 (E.D. Pa.), affd, 558 F.2d 821 (3d Cir. 1978); Pawlak v. Teamsters Local 764, 444 F. Supp. 807 (M.D. Pa. 1977), affd, 571 F.2d 572 (3d Cir. 1978). None of these courts analyzed $\$ 12(\mathrm{c})$, article XIX of the Teamster constitution which provides inter alia: "The appeals procedure provided herein is also available to and must be followed by any member who is aggrieved by any decision, ruling, opinion or action of the Local Union, membership, officers or Executive Board, excluding collective bargaining matters." Constitution and Bylaws of the International Brotherhood of Teamsters, art. XIX, $\$ 12$ (c) (adopted in June 1976) (emphasis supplied). This provision seems, on its face, to render intra-union exhaustion futile. See Chambers v. Local 639, Int'l Bhd. of Teamsters, 578 F.2d 375, 384 n.9 (D.C. Cir. I978). See also Miller v. Gateway Transp. Co., 103 L.R.R.M. 2591, 2593 \& n.6 (7th Cir. 1980) (Teamster constitution provides for only criminal-type prosecutions; similar to Bricklayers and Stonemasons constitution at issue in Orphan v. Furnco Constr. Corp., 466 F.2d 795 (7th Cir. 1972)).

164 See, e.g., Patterson v. Bailystoker \& Bikur Cholim, Inc., 95 L.R.R.M. 3115 (S.D.N.Y. 1977), in which the court denied the union's motion for summary judgment in part because "[n]o examples are provided where a member employed 
3. A Requirement that Unions Inform Members of Their Rights

To perpetuate any intra-union exhaustion doctrine in section 301 proceedings, the courts should at least be willing to abandon the axiom that ignorance of union procedures is no excuse for a member's failure to pursue or exhaust those procedures. It is one thing to require employees to exhaust contract grievance procedures, but another entirely to require them to exhaust intra-union appeals. On the one hand, unions are required to provide employees with copies of their contracts ${ }^{165}$ which, of course, set out the grievance procedure. Because unions have a duty to represent fairly all employees who may have grievances, even employees unfamiliar with the contract grievance procedures should be able to exhaust those procedures with the assistance of their union representatives. On the other hand, unions are not required to supply even their members with copies of their constitutions, which contain information about both the exhaustion requirement and the appeals procedures. ${ }^{186}$ Moreover, when the union ceases to be the employee's advocate in a grievance proceeding, and suddenly becomes his adversary in a potential intra-union disciplinary proceeding, one may safely assume that it will do little to inform the employee about, much less to assist him in exhausting, intra-union remedies. Most union constitutions also prohibit outside legal counsel from representing members in intra-union proceedings. Under these circumstances, it is absurd to think that a union member will, by himself, be able to pursue quasi-judicial union procedures or effectively to advocate a union breach of its statutory duty of fair representation.

Accordingly, if the courts accept the intra-union exhaustion doctrine under any circumstances, they should impose upon unions a duty to inform the member specifically of his intra-union remedies at the time that his grievance is withdrawn. The member should also be informed that the union tribunal is empowered to reactivate his grievance before the contract statute of limitations expires. Finally, if the exhaustion process is to be a meaningful one, the union should be required either to provide the member with an unbiased representative or to permit him to retain his own counsel. Of course, the union would then have to prove that the member

an intra-union appeal procedure to redress a failure by the union to duly represent him." Id. 3116. According to David Klein, Counsel to the UAW's public review board, not even the UAW can claim that more than one member has secured intraunion relief, though more than one-third of all appeals heard by the board involve the processing of grievances. Klein, supra note 6, at 103.

165 See LMRDA § 104, 29 U.S.C. \$414 (1976).

106 LMRDA $\$ 201($ a), 29 U.S.C. $\$ 431$ (a) (1976). See note 95 stpra. 
was aware of each of these items, and the court would have to be willing to invest considerable time addressing these ancillary issues, before a member could be penalized in any manner for failing to exhaust intra-union remedies.

\section{Problems that Lie Afead}

The discussion in part I demonstrated the undesirability of applying the requirement of intra-union exhaustion to any section 301 litigation. Although part II uncovered an exceptional situation in which the requirement might be justified, problems would undoubtedly arise in applying the exhaustion doctrine even in these narrow circumstances. The ability of employees to obtain full relief after their grievances have been reactivated by union tribunals is somewhat doubtful. Arguably, by ordering a member's grievance reactivated, a union tribunal has implicitly found that a breach of the duty of fair representation occurred. The employer could then argue that it should not be liable to the extent that the union's initial failure to prosecute the grievance "enhanced or contributed to the employee's injury." ${ }^{167}$ Although arbitrators generally possess the authority to determine contract claims and to award damages against employers, they are usually not authorized to determine fair-representation issues or to assess money damages against unions. Indeed, if they were so authorized, union tribunals would hesitate to invite damage awards by reactivating grievances unless they considered the union's potential liability to be negligible.

We are left with the question whether an employee who succeeds in having his grievance reactivated and ultimately wins a favorable award will be able to obtain complete relief. Manica $v$. Chrysler Corp.168 affords some insight into the question. The collective bargaining agreement between the UAW and Chrysler permitted the union to reactivate withdrawn grievances within a threemonth period but explicitly absolved Chrysler of financial liability accruing from the time the grievance was dropped until it was later reactivated. Even if the employee's grievance were eventually sustained, the employee would still be unable to recover full back pay from Chrysler. Unless the union were willing to compensate him for the difference, the employee would still be forced to seek judicial relief to complete his remedy. ${ }^{109}$ There is no guarantee, there-

167 Vaca v. Sipes, 386 U.S. 171, 187 (1967).

16897 L.R.R.M. 2679 (E.D. Mich. 1978).

169 Even when the union "restores" fair representation not only by reactivating a member's grievance, but also by properly prosecuting the grievance thereafter (perhaps by assigning a representative to assist the grievant other than the individual 
fore, that intra-union exhaustion will result in the prompt and complete resolution of employee contract claims or the conservation of judicial resources, even when the contract allows grievances to be reactivated.

Similarly, imposing a four-month time limit will not resolve all problems. One may wonder, for instance, when the four-month period should begin: when the employee's grievance is withdrawn or abandoned by his union; when the employee receives notice that his grievance has been dropped; when the employee initiates his union appeal? 170 Consider, for example, an employee who has failed to pursue his union appeal for a year or more after his grievance was withdrawn because he was unaware of his union's appeals procedures until the lawyer he retained to bring a section 301 suit informed him of the exhaustion requirement. Should the fourmonth time limit begin to run before the employee is, or should have become, aware of an appeals procedure?

Or, suppose that a grievant is aware of his union's appeals procedure but deliberately fails to press his appeal within four months, or any other limitations period which might obtain, in order to have his claim decided by a court rather than by an arbitrator. Should the court impose any penalty, either by dismissing the claim or by sending the grievant back to the union for four months of exhaustion? Should the court have to inquire about the employee's intentions or the point at which he learned of his union's procedure?

Under even the most ideal circumstances, have the problems of bias and financial interest on the part of union tribunals been eliminated? Would union tribunals be willing to reactivate even the most meritorious grievance for fear of inviting an eventual court awvard of damages against the union for aggravating the employee's injuries by its delay in prosecuting his grievance?

Another continuing problem is the differing treatment of nonmembers, "nominal" members, and full-fledged union members. Should "nominal" members who joined the union only because membership was a condition of employment under a union-security clause in their contract be required to exhaust union appeals? And, is it fair to saddle union members with the exhaustion requirement

responsible for originally withdrawing or abandoning the grievance), this action would not relieve the union of liability to the employee for injuries he may have sustained as a result of the delay in securing his contract rights occasioned by the union's initial refusal to prosecute his grievance.

170 Cf. Newgent v. Modine Mfg. Co., 495 F.2d 919, 928 (7th Cir. 1974) ("[n]ecessarily implied . . . is the duty to become aware of the nature and availability of union remedies"). See also cases cited in note 80 supra. 
if it cannot be extended to non-members under any circumstances? Suppose there is a provision in the collective bargaining agreement possessed by, and admittedly covering, all employees, members and non-members alike, authorizing union tribunals to reactivate grievances. Are non-union employees given notice by such a provision sufficient to impose a duty to discover and pursue union appeals? Suppose the contract refers to, or incorporates by reference, the appeals provision in the union constitution. Or, suppose the contract itself elaborates the union appeals procedure available to employees seeking to have withdrawn grievances reactivated. Would the intra-union procedure then become a part of the contract grievance procedure so as to require the employee either to exhaust or to demonstrate why it would be futile to do so under Republic Steel Corp. v. Maddox? ${ }^{171}$ Of course, if this were the result, the employee would again bear the burden of demonstrating the futility of pursuing procedures with which he has no familiarity-procedures which are inherently unlikely to yield any relief.

\section{CoNCLUSION}

The intra-union exhaustion requirement has been imported into section 301 litigation without any serious examination of its appropriateness in this context. Given the unique, hybrid character of the section 301 action, and the possible applicability of intra-union review only to a single claim, the exhaustion requirement works little more than mischief. Indeed, the policy arguments advanced to justify its uncomfortable presence in section 301 litigation prove, on close analysis, to be fanciful. The various interests said to be served by the doctrine are not in fact advanced, and the price of these illusive benefits is substantial interference with the ability of individual employees to vindicate their rights under collective bargaining agreements, rights which the Supreme Court has repeatedly affirmed.

Only in the highly unusual case in which the collective bargaining agreement allows union tribunals to reactivate grievances, may the intra-union exhaustion doctrine be defended on the ground that the grievance may yet be resolved pursuant to contract grievance procedures-the route favored by federal policy. Even in this case, however, procedural safeguards for individual grievants would have to be developed-a process which leads to a swamp of intractable problems and argues for total abandonment of the intra-union exhaustion doctrine in cases in which employees are seeking to 
vindicate statutory and contractual, as opposed to union-constitutional, rights.

The source of these problems is, once again, the fact that section 301 litigation requires the reconciliation of a variety of conflicting interests; according to NLRB $v$. Industrial Union of Marine \& Shipbuilding Workers, it is a "complex problem concerning employer, union and employee member." ${ }^{172}$ And, as the Supreme Court said in Vaca v. Sipes: "These [section 301] remedy problems are difficult enough when one tribunal has all parties before it; they are impossible if two independent tribunals, with different procedures, time limitations, and remedial powers, must participate." 173 Instead of making marginal adjustments to the intra-union exhaustion doctrine which in turn yield a second generation of unwieldy problems, the courts may well conclude that intra-union exhaustion has no place in section 301 litigation.

Complete abandonment of the intra-union exhaustion doctrine in section 301 litigation would mean only that the courts would have to resolve unfair-representation claims, just as many courts do even when failure to exhaust is proven and cited as a reason for dismissal. At the same time, individual employees would be given a chance to prove unfair representation and, if successful, to vindicate their collective bargaining rights. The balance of interests clearly favors annulment of the judicial marriage of the intra-union exhaustion doctrine to section 301 litigation. In the words of an astute observer of life and law: "Many a good hanging prevents a bad marriage." 174

172391 U.S. 418,425 (1968).

173386 U.S. 171, 188 n.12 (1967).

174 W. ShakEspeane, TWELFTH Night act $i$, sc. 5. 